\title{
DETERMINANTS OF UNEMPLOYMENT DURATION IN UKRAINE
}

\section{Olga Kupets}

This paper presents first evidence on the determinants of unemployment duration in Ukraine between 1997 and 2003, using individual-level data from the first wave of the Ukrainian Longitudinal Monitoring Survey (ULMS -2003). It investigates the conditional probability of an individual leaving unemployment to employment or economic inactivity in any particular month of his spell out of work by estimating it in a discrete time independent competing risks framework with flexible baseline hazard rates and gamma-distributed unobserved heterogeneity. The results in all specifications indicate no significant effect of receiving unemployment benefits but significant negative effect of having income from casual activities, subsidiary farming, household income or pension on the hazard of reemployment. Multivariate analysis also suggests that policies to reduce long-term unemployment should focus on older workers, less educated individuals, residents of small towns and rural area in the regions with relatively high unemployment rates.

\section{JEL Classification: J64, J68, P23}

Keywords: Long-term unemployment, unemployment insurance, Ukraine, semiparametric duration analysis, flexible baseline hazard.

Acknowledgements. The author is grateful for the constructive criticism and helpful comments from Rostislav Kapelyushnikov, Hartmut Lehmann, Irina Denisova, Michael Beenstock, Reuben Gronau, Klara Sabirianova, John Earle, Christian Belzil, Atanas Christev, Anna Lukyanova, Inna Maltseva, and participants of the IER (Kiev) Conference on Labor Market Reforms and Economic Growth in Ukraine: Linkages and Policies in Kiev (March, 2004). Financial assistance from the EERC (Russia) on grant R02-237, from INTAS (Belgium) on grant YS 2002-249/F7, and from the Economics Research and Outreach Center (EERC, Ukraine) is gratefully acknowledged. Special thanks to the Institute for the Study of Labor (IZA, Bonn) as the INTAS host institution for support and hospitality. Data for this study are taken from the first wave of the Ukrainian Longitudinal Monitoring Survey (ULMS) which has been carried out by the Kiev International Institute of Sociology on behalf of the international consortium of sponsors led by the Institute for the Study of Labor (IZA, Bonn, Germany).

\section{Olga Kupets}

Economics Research and Outreach Center

Economics Education and Research Consortium

National University "Kiev-Mohyla Academy"

Voloshskaya str., bld.10, office 214

$04070 \mathrm{Kiev}$, Ukraine

Tel.: (38-044) 239-24-94

Fax: (38-044) 239-24-90

E-mail: kupets@eerc.kiev.ua 


\section{NON-TECHNICAL SUMMARY}

The persistent and stagnant character of unemployment over the last decade in Ukraine has become an overwhelming concern for policymakers and for society in general. The problems of unemployment are aggravated even more because the incidence of long-term unemployment and the average duration of unemployment appear to have decreased slowly in response to increases in labor demand in previous years. This implies that there are potentially serious barriers existing between long-term unemployed and new job opportunities. Consequently, one possible way to tackle the problem of long-term unemployment in Ukraine is to combat the inflow into long-term unemployment by offering more assistance to job losers before they reach the stage of long-term unemployment (i.e. preventive measures). A second important way is to apply measures focused on the needs of the more disadvantaged groups which aim at reducing the existing stock of chronic unemployed. In this context, it is of vital importance to understand the forces which tend to shape the structure of unemployment duration and its dynamics in order to properly design the social and economic policy model. The main purpose of this study is to determine factors which affect the probability of reemployment or withdrawing from the labor force after a period of unemployment in Ukraine over the last years. In particular we look at the impact of unemployment benefits and alternative sources of income during an unemployment spell, various individual and local labor market characteristics.

The theoretical framework of our empirical study is job search approach. This paper builds on previous works in developed countries by estimating the conditional probability of leaving unemployment in a discrete time independent competing risks framework with flexible baseline hazard rates and gamma-distributed unobserved heterogeneity. The data base is a sample of unemployment spells experienced by individuals over the period December 1997 - June 2003 from the first wave of the Ukrainian Longitudinal Monitoring Survey (ULMS - 2003).

In this study we test several basic hypotheses, namely about insignificant impact of receiving unemployment benefits on the probability of leaving unemployment, about disincentive effect of income from casual activities, subsidiary farming or other alternative sources of subsistence, about significant impact of individual characteristics (demographic attributes, measures of human capital and previous labor market history) and labor market (local and national) conditions. Our results suggest that on average low non-employment benefits in Ukraine cannot be considered as the significant determinant of unemployment duration in contrast to empirical evidence in many developed and transition countries. However, the possibility of receiving income from different casual activities or subsidiary farming, labor market age discrimination, occupational and geographic imbalances can potentially explain the stagnancy of unemployment in Ukraine. 


\section{INTRODUCTION}

After more than ten years after the start of transition in the CEE and CIS countries, there is still considerable debate about the different labor market adjustment paths in the CEE versus CIS countries. Why, on the one hand, these countries with almost similar initial conditions can be characterized by roughly similar pattern of GDP with strong declines after the introduction of political and economic reforms and its gradual growth after the positive sign of recovery, while on the other hand, responsiveness of employment to output changes and unemployment dynamics are so much different?

A large body of both theoretical and empirical literature has been developed to suggest various explanations of these asymmetries in transition process between CEE and CIS countries. The OST (optimal speed of transition) literature attributes asymmetric labor market adjustment paths to differences in economic policies, particularly in the pace of the tightening of budget constraints of state enterprises (Blanchard, 1997). Boeri and Terrell (2002) and Boeri (2001) argue that differences in the adjustment of the labor market during transition may be partly explained by labor supply factors and the role played by non-employment benefits. As they point out, the CEE countries adopted social policies that created a wage floor implying relatively high labor costs. On the one hand, this wage floor forced to release unproductive resources for more productive activities (i.e. some Schumpeterian "creative destruction" (Davis and Haltiwanger, 1999) translated in the relatively large growth rates, but on the other hand, it resulted in the build-up of very stagnant unemployment pool due to low outflow rates from unemployment. In the CIS, on the contrary, the costs of labor are much lower because nonemployment benefits are very low, and various specific adjustment mechanisms such as wage arrears, unpaid leave, reduced working week and payment in-kind are extensively used (as documented by Lehmann et al., 1999, and Earle and Sabirianova, 2000). These low labor costs imply that labor hoarding is still existent in many enterprises, especially in the state sector, and that the reservation wage is also very low. So, while low labor costs impede "creative destruction", they also mean that outflows from unemployment are relatively large and that unemployment is less stagnant.

However, the idea that there are large outflows from unemployment in the CIS is an assertion that is based mainly on the evidence for Russia in the early period of transition (e.g Commander and Coricelli, 1994; Commander and Yemtsov, 1994; Foley, 1997b for 1992-93). Denisova (2002) argues that unemployment in Russia during the last years appears to be stagnant, with the ratio of long-term unemployed in unemployment pool of more than thirty percent.

Table 1 on the distribution of unemployment by duration in Ukraine in 2000-2003 reveals that Ukraine faces even more severe problem of long-term unemployment: . So the picture of a large turnover in the pool of unemployment envisaged for CIS countries by Boeri and Terrell (2002) appears to be not very accurate in the case of Ukraine. It seems that the labor market adjustment path in Ukraine may extend a number of puzzles of transition and so makes a particularly interesting case for 
investigation. On the one hand, low labor costs due to low non-employment benefits and high wage flexibility hinder fast effective labor reallocation like in Russia. ${ }^{1}$ On the other hand, low unemployment benefits and social assistance have not resulted in the large outflows from unemployment - unemployment in Ukraine has becoming stagnant as in the CEE countries. In this study, we try to shed some light on the effect of non-employment benefits, supply- and some local demand-side factors on the exits from unemployment in Ukraine. ${ }^{2}$

What are the factors that determine the probability of leaving unemployment in Ukraine? Does the Ukrainian unemployment insurance system discourage quick exits to employment or some other factors come into effect instead? What individuals are most exposed to long-term unemployment? These are the questions we attempt to answer in our study whereby filling gap in the literature on determinants of unemployment duration in Ukraine. The main purpose of this study is, therefore, to examine factors which affect the probability of reemployment or withdrawing from the labor force after a period of unemployment in Ukraine over the last years.

We use individual data from the first wave of the Ukrainian Longitudinal Monitoring Survey (ULMS), which contains rich information about the individual's labor market history, geographical mobility, history of studies and changes in marital status owing to its retrospective nature. These data provide accurate information on unemployment spell duration and other important characteristics for 1799 individuals over the period 1997-2003. Some of the unemployment entrants subsequently leave this labor market state to employment or inactivity within a few weeks, while others tend to remain unemployed during several years. Some persons experience unemployment only once during the observed period, while the others may have from two to five unemployment spells. There is, therefore, enormous variation in the duration of unemployment spells across individuals in our sample, which allows us to analyze the underlying causes of these striking differences. Competing risks of exits to employment and to inactivity are estimated by using the discrete-time complementary log-log model with a fully flexible nonparametric specification of the baseline hazard and comparing it to the alternative approaches, the discrete-time complementary log-log model with polynomial form of the baseline hazard and continuous-time Cox partial likelihood proportional hazards model. Our model along with other flexible duration models yields more robust results than those obtained from commonly used Weibull or other parametric models (Meyer, 1990; Han and Hausman, 1990). In our

\footnotetext{
${ }^{1}$ Extensive analysis of unemployment in Russia and its comparison with other transition countries is provided in Kapelyushnikov and Vishnevskaya (2003).

${ }^{2}$ The difference in the rate of long-term unemployment between Russia and Ukraine can be partly attributed to the different patterns and magnitudes of job flows in these countries. Brown and Earle (2002) show that increases in job reallocation and in the productivity-enhancing consequences of the labor reallocation process appears to have been somewhat slower in Ukraine than in Russia, implying that a more aggressive reform strategy implemented in Russia has produced greater job reallocation, faster job creation, and less net employment decline, translated in higher intensity of flows into and out of unemployment and shorter unemployment duration.
} 
estimation we allow for gamma-distributed unobserved heterogeneity but it appears to be not important since explicitly modeling unobserved heterogeneity changes the covariates little. ${ }^{3}$

The paper is set up as follows. Section 2 provides an overview of unemployment insurance system and labor market trends in Ukraine. Section 3 describes the conceptual framework and the econometric model to be used in the analysis. Section 4 gives the details of the data and variables used. Section 5 presents our estimation results and Section 6 offers conclusions and recommendations.

\section{THE CHALLENGE FOR AN UNEMPLOYED IN UKRAINE:}

\section{UNEMPLOYMENT INSURANCE OR ALTERNATIVE SOURCES OF SUBSISTENCE?}

Public Employment Service (PES) and unemployment benefit system have been established in Ukraine according to the Law on Employment in 1991 when Ukraine was one of the republics of the Soviet Union. So despite many amendments to the Law in independent Ukraine during 1991-2003, there are still many similarities in regulations connected with unemployment between Ukraine and other FSU countries. ${ }^{4}$ In general, the PES in Ukraine as well as in any other country is supposed to perform two major functions: to assist unemployed workers in their job search and to provide income support during a period of unemployment.

But it is widely believed that the Ukrainian PES is not very successful in both of the tasks. Firstly, although firms are obliged to register all vacancies with the local employment center and to make use of it in recruitment, many firms fail to do this preferring other channels for recruitment due to weak law enforcement. Besides, sometimes PES provides training or retraining for the skills that are already in surplus in the local labor markets, and public works are usually of low skill level (Kuzmin et al., 2003; Kupets, 2000). So the probability of more effective matching and finding a good job with the help of the public employment center is small, while the transaction costs of registration and staying at the register are high. ${ }^{5}$ Secondly, the level of unemployment benefits is too low: the ratio of the average unemployment benefits to the average wage in the economy is about $25-28 \%$, while the ratio of the average unemployment benefits to the nationally established level of minimum wage fluctuates between 50 and 70\% (Table 2, bottom lines). Moreover, because of the strict unemployment benefit eligibility criteria and high incidence of long-term unemployment, the coverage ratio (the ratio of those receiving unemployment benefits or unemployment assistance to the total number of registered unemployed) has been less than $70 \%$ during all years. Although the unemployment insurance system

\footnotetext{
${ }^{3}$ The empirical work of Meyer (1990) and of others suggests that when the baseline hazard is fully flexible, failure to model distribution of unobserved heterogeneity explicitly does not seriously bias results.

${ }^{4}$ Main institutional characteristics of the unemployment insurance system in Ukraine can be found in Appendix 1.

${ }^{5}$ One of such transaction costs of staying at the register is a necessary visit (report) of unemployed to the local employment center once a month in the administrative center of their civil registration (new name of the old system of propiska). Since many people live far from administrative centers of their propiska, the above requirement demands too heavy expenses in terms of time and money.
} 
in Ukraine may seem better than in the CEE countries from the viewpoint of incentives/disincentives to work, it is certainly worse in terms of income support of jobless workers and prevention of their falling into poverty.

As a result, less than half of the actual jobless workers in Ukraine (defined according to the ILO unemployment criteria) bother to register as unemployed in the public employment offices (Table 2). Analysis of job search methods among unemployed in our sample (Table 3) indicates that people rely primarily on their direct contacts with employers, help of friends and relatives, or advertisements in the newspapers or Internet rather than on the assistance of the public employment offices.

This suggests that unemployment insurance system is not likely to play a significant role in determining duration of general unemployment in Ukraine. However, another explanation originated from the weak enforcement of the Labor Code and other laws and high payroll taxes is called into play. As in many transition countries, there are many possibilities for informal activities and unregistered employment in Ukraine, often casual and very short-term. ${ }^{6}$ As has been documented by Mel'ota and Gregory (2001), the informal activity in the household sector in Ukraine amounts to about $16 \%$ of official GDP and presents the main source of the shadow economy in the country. Because of very low unemployment benefits accompanied with still relatively low labor demand, many people start some sort of self-employment just to survive, other leave the formal labor market preferring to find an informal activity or to rely on subsistence farming, and some persons withdraw from the labor market looking for additional sources of income like stipend, pension, child allowance, etc. Therefore, we suggest that there are likely individuals among long-term unemployed who search less intensively for regular job because they are occasionally engaged in unreported activities or subsistence farming which provide them sources of subsistence. ${ }^{7}$ Additionally, alternative income during the period of unemployment raises reservation wage of such individuals whereby lowering the probability of then accepting the job offer and the probability of re-employment on the whole. Various kinds of non-labor income during a period of unemployment including household income, state and private transfers, investments, savings, etc. are likely to have the same effect on duration of unemployment as casual labor income reducing the probability of reemployment and thereby extending the period of unemployment. ${ }^{8}$

Therefore, we test the hypothesis that whether an unemployed receives unemployment benefit or no is not significant for his/her probability of exit from unemployment. ${ }^{9}$ At the same time, we

\footnotetext{
${ }^{6}$ According to Vodopivec (1995) and Grogan and van den Berg (1999), informal employment among unemployed is also widespread phenomenon in Slovenia and Russia, respectively.

${ }^{7}$ Discussion of the definition of unemployment adopted in our study is provided in Section 4 on Data.

${ }^{8}$ Distribution of responses on the main source of subsistence among unemployed in our sample (aggregated to five main groups which will be used later in our analysis) is provided in Table 4.

${ }^{9}$ We use dummy variables for various groups of sources of subsistence which reflect only presence or absence of particular type of income during the period of unemployment because it is impossible to estimate the amount of income, received by unemployed persons from various sources, using the ULMS data. Hunt (1995) finds for Germany that dummy on receipt of
} 
hypothesize that existence of alternative sources of subsistence during an unemployment spell significantly extends a period of unemployment, though this factor can not be considered as of primary importance. Following Ham et al. (1998) and Arulampalam and Stewart (1995), we suggest that the factors from the labor demand side may be considered the dominant in explaining stagnancy of unemployment in Ukraine, but we should not forget also that supply-side determinants can be also at play (Boeri, 2001). Similar to many other transition economies, there are likely displaced workers in Ukraine who can not find a new job easily because their skills acquired under the Soviet era are obsolete and they are reluctant to retrain. Great difficulties for some groups of unemployed to find a new regular job accompanied with disincentive and discouragement effect may lead to long unemployment durations before re-employment or to higher outflows to inactivity. We investigate to what extent this is the case in Ukraine in the rest of the paper.

\section{ECONOMETRIC MODEL}

The typical framework used in the empirical analysis of unemployment duration is the job search theory presented in Mortensen (1970). The focus in modeling duration of unemployment is usually on the conditional probability of leaving unemployment, the hazard function. ${ }^{10}$ The theoretical model of job search in a two-state labor market (employment and unemployment) implies that the hazard function can be viewed as the product of the probability of receiving a job offer (which could be further decomposed into a contact rate and an employer acceptance rate) and the probability then of accepting this job offer determined by his/her reservation wage. Thus, the expected length of an individual's unemployment spell depends on the effort an individual makes to find a new job (job search intensity), the attractiveness of a person to an employer and local labor demand conditions, a wage offer distribution and the lowest acceptable wage, i.e. reservation wage. ${ }^{11}$

The econometric model adopted in our study is Cox proportional hazards model (Cox, 1972):

$$
\lambda_{i}(t)=\exp \left(\beta^{\prime} X_{i}\right) \lambda_{o}(t),
$$

\footnotetext{
UI is significant while the level of benefit receipt is insignificant. Addison and Portugal (2001) use dummy on access to unemployment benefits and find it highly significant in Portugal, but they group individuals by age (seven elements of age regressor) so that to "mimic the stepped increases in benefit entitlement with age". We think that dummy variable on receipt of unemployment benefits in our case is enough to capture the expected effect of UI on unemployment duration, given small variation in the level of unemployment benefit and duration of its payment among benefit recipients in Ukraine.

${ }^{10}$ See Kiefer (1988) or Lancaster (1990) for more details on duration models and hazard function.

${ }^{11}$ It should be noted that we use a reduced form approach, which implies that the total effects of the variables on the probability of re-employment are estimated rather than separate effects on the probability of receiving a job offer and probability of accepting a job offer.
} 
where $X_{i}$ is a vector of explanatory variables for individual $i$ (we assume that all variables are timeinvariant), $\beta$ a vector of parameters to be estimated, and $\lambda_{0}(t)$ the 'baseline' hazard capturing the duration dependence of the hazard. ${ }^{12}$

If durations are measured in terms of whole months completed (interval-censored data), an observed duration of $t$ whole months indicates duration on the continuous-time scale of between $t$ and $t+1$ months. According to Meyer (1990), if there are no time-varying variables or if the value of timevarying variables is constant between $t$ and $t+1$, the probability of a spell being completed by time $t+1$ conditional on that it was still continuing at time $t$, the discrete-time hazard, can be written in the complementary log-log form as follows:

$$
\begin{gathered}
\lambda_{i}(t)=1-\exp \left[-\exp \left(\beta^{\prime} X_{i}+\gamma(t)\right)\right], \\
\gamma(t)=\ln \left[\int_{t}^{t+1} \lambda_{0}(u) d u\right]
\end{gathered}
$$

where

is some functional form which summarizes the pattern of duration dependence in the discrete time hazard. We prefer a flexible specification of the baseline hazard since it allows for non-monotonic variation with duration, and therefore a wider range of possible effects of duration on the hazard rate can be captured (Meyer, 1990; Han and Hausman, 1990). The shape of the baseline hazard is estimated in our model on a month by month basis without any restrictions on how $\gamma$ can vary from interval to interval. In other words, we employ a flexible parametric (semiparametric) proportional hazards model: the baseline hazard is non-parametric while the effect of covariates takes a particular functional form.

In this study we distinguish between two destination states of exits out of unemployment (competing risks): unemployment can end with finding a regular job or with a spell of economic inactivity. Following the assumption made by Narendrenathan and Stewart (1993) for intervalcensored data, that exits from unemployment can only occur at the interval boundaries and that risks are independent, the overall independent competing risks model simplifies to two or more single-risk models analogous to that for continuous time data. ${ }^{13}$ To estimate the two risks separately, exits from unemployment to inactivity are considered censored when estimating exits to employment, and vice versa.

Finally, to allow for unobserved heterogeneity we extend our model introducing a gammadistributed random variable $v$ in each of the destination-specific hazard and assuming the independence across terms.

\footnotetext{
${ }^{12}$ The proportional hazards model assumes that absolute differences in explanatory variables result in proportionate differences in the hazard at each $t$.

${ }^{13}$ An alternative assumption for the discrete-time competing risks model can be found in Han and Hausman (1990).
} 


\section{DATA AND DEFINITION OF VARIABLES}

The data employed to analyze the probability of leaving unemployment in Ukraine are taken from the first wave of the Ukrainian Longitudinal Monitoring Survey (ULMS)-2003, a nationally representative random sample of households. It has information about 4,056 households and 8,641 individuals aged from 15 to 72 . The ULMS data set is a unique one in Ukraine since it is the first data set available at the individual level and it allows making an analysis of the labor market flows and unemployment duration from December 1997 till the reference week in 2003 owing to its retrospective nature.

Our sub-sample consists of individuals with at least one unemployment spell between December 1997 and June 2003 who provided complete responses to the questions about the period of job search. As a result, we have 2122 unemployment spells experienced by 1799 individuals, with the average number of unemployment spells per person of 1.18 and its maximum number of $5 .{ }^{14}$ We distinguish the following three types of unemployment spells by destination states:

- exit to employment if a respondent has found a job (or started his business) after a period of job search,

- exit to inactivity if a respondent has stopped job search, and

- right-censored if the period of job search has been continuing at the date of an interview.

Our 'dependent' variable is the length of an unemployment spell defined as the number of full months between the date of beginning of job search (month and year only) to the date of its end. ${ }^{15}$ To each unemployment spell experienced by a sample member we have attached a vector of demographic and other individual characteristics (including gender, age, marital status and number of small children, education, sources of subsistence during unemployment, previous labor market status, previous unemployment experience), the values for which are determined at the starting date of the unemployment spell to ensure their exogeneity. In addition to individual characteristics, we use variables to account for differences in local labor demand conditions. Differences in the local labor markets are proxied in our study by regional unemployment rate (accounting for between-region

\footnotetext{
${ }^{14}$ In our study, a person is classified as unemployed if: 1) he/she answered that he/she didn't have a job (including entrepreneurship, business activities, individual work, work in a family enterprise or on a farm, and freelance work) at some time period in the past; 2) a person gave the reason of not having a job and answered that he/she was seeking and available for work for any time during that non-employment period; 3 ) there is no overlapping in time between the period of employment and the period of non-employment according to respondent's answers (if there was such overlapping we reclassify this person as employed).

${ }^{15}$ The minimum length of the periods fixed in the ULMS is one month. If, for instance, there was a period of less than a month between leaving one job and starting a new one, this period is not reflected in the questionnaire as a separate period of unemployment.
} 
differences) and the type of settlement (accounting for within-region differences). ${ }^{16}$ Finally, we add the year and the quarter of entering into unemployment to control for changes in macroeconomic environment and possible seasonal effects. The definitions of all variables are provided in Appendix 2.

Table 5 provides some descriptive statistics for the variables used in the unemployment duration analysis. It shows that one half of unemployment spells ends with a transition to employment, and censored spells account for the next largest proportion of unemployment spells. The mean duration of both completed and uncompleted unemployment spells is about 17 months, with $46.5 \%$ of all spells lasting more than 12 months. ${ }^{17}$ Distribution of unemployed persons with uncompleted spells by actual duration of their unemployment at the moment of interview shows that the share of long-term unemployed is $48 \%$ of all 'currently' unemployed according to the ULMS data. ${ }^{18}$ This suggests that long-term unemployment remains an important issue in Ukraine even in stronger labor market conditions after economy's reversal and needs more careful investigation.

Before proceeding to discussion of the results, several important points should be noted. First, there can be some difficulties connected with definition, measurement of unemployment and further comparison of unemployment measures from various sources. Although we follow the ILO (1982) guidelines on defining the unemployed as persons without work, looking for work and available for it during a given period of time, the definition of unemployment accepted in our study differs from the standard ILO definition due to retrospective nature of the data with a long recall period:

- since labor market states are measured in relation to a long reference period such as several years rather than to a short period such as one week or one day, definition of the three labor market states employed in our study refers to the "usually" employed, unemployed or economically inactive rather than to the "currently" employed, unemployed or economically inactive individuals;

- according to the standard ILO unemployment criteria individuals who engage in casual work or casual business activities can not be classified as unemployed. In our study, however, we do not exclude individuals on the basis of their engagement in irregular businesses from the sample of unemployed if: 1) a person answered that he/she didn't have a job (including entrepreneurship, business activities, individual work, work in a family enterprise or on a farm, and freelance work) at some time period in the past; 2) a person gave the reason of not having a job and answered that he/she was seeking and available for work for any time during that period; 3) there is no

\footnotetext{
${ }^{16}$ We prefer information on registered unemployment rather than unemployment from the LFSs because of consistency in methodology and completeness of information at the quarterly basis by regions for the former indicator in contrast to the latter.

${ }^{17}$ Due to limitation of the minimum length of the periods fixed in the ULMS to one month and retrospective nature of the ULMS, its sample tends to be biased towards long unemployment spells and this fact should be taken into account when analyzing duration of unemployment.

${ }^{18}$ For comparison, according the LFS data (2003:II) the share of unemployed with duration of non-employment of more than 12 months is $61 \%$ of all unemployed previously employed, and the share of unemployed with duration of job search of more than 12 months is $54 \%$ of all unemployed who were looking for work during the preceding four weeks.
} 
overlapping in time between the period of employment and the period of non-employment according to respondent's answers (if there was such overlapping we reclassified a person as employed); and 4) a person pointed to income from casual work or business activities, production and sale of products from own land plot, or subsidiary farming for own needs as one of the sources of subsistence at that time of non-employment. Unfortunately, the ULMS doesn't let to capture accurately the extent and the nature of such irregular, usually short-term, activities within a long period of non-employment. It is impossible to know for sure whether casual work or business activities in this case are really short-term and sporadic or they have systematic character; whether persons without formal job attachment have chosen these informal activities in view of formal sector opportunities, or they have been forced to engage in casual work activities or subsidiary farming just to survive ${ }^{19}$;

- we didn't put any restrictions on age of individuals in the sample as it is usually done using the retirement age as a threshold (e.g. Foley, 1997a; Grogan and van den Berg, 1999, among others) since we think that due to low retirement age accompanied with very low pension (less than $30 \%$ of average wage) in Ukraine persons aged above retirement age have the same work incentives as those in pre-retirement age group. Moreover, according to the ILO guidelines, pensioners, students and others mainly engaged in non-economic activities during the reference period, who at the same time were in paid employment or self-employment above should be considered as employed on the same basis as other categories of employed persons, and persons who satisfy the basic criteria of unemployment should be classified as unemployed. We control for those who receive any kind of pension (not only for years of service or retirement age but also for disability and loss of provider) during a period of unemployment by including a separate dummy for such persons in one of our specifications.

According to Poterba and Summers (1995), although some categories of individuals classified as "out of the labor force" are conceptually distinct from "unemployed" (e.g. disable or retired in the US), substantial portion of those reporting themselves as economically inactive may be reclassified as unemployed, and vice versa. Therefore, some allowance for spurious events that result from classification error should be made when analyzing unemployment duration and dynamics.

Second, we might expect that the problem of classification error may aggravate as we go further back in time asking about unemployment periods. ${ }^{20}$ Our analysis based on the retrospective data over more than five years is certainly subject to reliability problems and recall bias (see Sudman and Bradburn, 1973; Morgenstern and Burrett, 1974; Akerlof and Yellen, 1985; Dex and McCulloch,

\footnotetext{
${ }^{19}$ Sabirianova (1998) has estimated that in the case of Russia unemployment rate according to the standard ILO definition should be corrected (increased) for $1-2 \%$ if the unemployment sample is augmented with the number of non-employed individuals having casual income during a period of job search.

${ }^{20}$ Paull (2002) argues that time in unemployment is less likely to be recalled correctly than periods of employment and inactivity, and so the spell of unemployment may be reclassified as the spell of inactivity rather than forgotten at all.
} 
1998; Paull, 2002, among many others). But we believe that relatively low labor market mobility of the majority of Ukrainian population, salience and social undesirability of unemployment spell for most of individuals, and the careful design of the questionnaire minimize this problem.

\section{ESTIMATION RESULTS ${ }^{21}$}

To assess the joint effect of various individual and labor market characteristics affecting the probability of exit from unemployment we employ three specifications in a competing-risk framework distinguishing between exits to employment and exits to economic inactivity: two discrete-time complementary log-log models, one with fully flexible non-parametric baseline hazard like in Meyer (1990) and the other with a polynomial baseline hazard, and a continuous-time Cox proportional hazard model (Tables $6 \mathrm{a}$ and $6 \mathrm{~b}$ ). ${ }^{22} \mathrm{We}$ also estimated the models allowing for unobserved heterogeneity (gamma distributed) but the variance of the heterogeneity is not significantly different from zero as for exits to employment as for exits to inactivity implying that no unobserved heterogeneity is found in our case. ${ }^{23}$

To account for the possible correlation between spells experienced by one person (serial correlation) for the individuals with multiple spells of unemployment we include variable on the number of previous unemployment spell to the estimation model and also fit all our models with the robust standard errors adjusted for clustering on the individual identification. Furthermore, we estimated also the models using subsample consisting of individuals who experienced only one unemployment spell during the observation period but the results have not changed significantly. Thus, we can suggest that serial correlation might not be a problem in our case and the behavioral model for the persons with several unemployment spells doesn't differ significantly from those without previous unemployment experience.

Table 6a presents estimation results for the determinants of unemployment duration before reemployment. The first three models use the same explanatory variables, but different specifications for the baseline hazard. The significance, signs and magnitudes of the estimated coefficients in models (1)-(3) are almost identical, so we base our interpretations on the estimates of the model with

\footnotetext{
${ }^{21}$ Here presented only results of the multivariate semiparametric duration analysis. Results of the univariate non-parametric analysis (using Kaplan-Meier product limit estimators) are available at request. Graphs of the empirical survival and hazard functions are provided in Appendix 3, Figures 1-4.

${ }^{22}$ We have examined also the effect of religion, nationality, health status, the number of dependants younger than 15 or older than 75 in the household, previous employment status, sector of previous employment (according to the NACE classification), last occupation before unemployment spell (according to the ISCO classification), and national unemployment rate (controlling for macroeconomic climate) but these factors appear to be not significant, and our main results are robust to the inclusion of these additional variables.

${ }^{23}$ No significant frailty effect has been also found in Stetsenko (2003) for Ukraine and Grogan and van den Berg (1999) and Foley (1997a, for exits to employment) for Russia. Furthermore, Narendranathan and Stewart (1993), argue that "there is no reason for any resulting distortions connected with possible misspecifications through unobserved heterogeneity to be less serious than those caused by ignoring unobserved heterogeneity". Given these findings, we present final estimation results without accounting for unobserved heterogeneity.
} 
nonparametric baseline hazard (3). Model (4) is the same as model (3) with the only difference that it uses yearly regional unemployment rates according to the ILO methodology instead of regional registered unemployment rate incorporated in the other models. In model (5) we include the $\log$ of previous earnings with the same specification of the baseline hazard as in models (3) or (4). Finally, model (6) differs from the basic model (3) in that those who receive pension are separated from those who receive other kinds of state transfers. All models include yearly and quarterly dummies in order to control for macroeconomic environment and seasonal effects.

The results suggest that differences in hazards of exit to employment between men and women do not appear to be significant. Married women tend to have lower hazard rates from unemployment to employment although married individuals as a whole are more likely to leave unemployment to employment. This suggests that historically established pattern of family responsibilities in Ukraine is an important factor in the labor supply decisions. At the same time, the number of small children has no effect on the duration of unemployment. This finding may be partly attributed to the well functioning system of pre-school and out-of-school education developed under the Soviet Union with the aim of promoting women's labor force participation.

The age coefficients suggest that the probability of exit from unemployment to employment decreases with age and that older worker are at a disadvantage in a rapidly changing economic environment. The estimates in model (3) imply that at each survival time the hazard rate is approximately halved for persons aged between 40 and 54, and the hazard rate for those who are 55 or older is about one third of the hazard rate for those who are 24 or younger. These results are consistent with job search theory and empirical evidence for many transition countries (e.g. Foley, 1997a; Nivorozhkina, 2002; Stetsenko, 2003) but they contrast to the findings of many studies for the early period of transition about longer duration of unemployment among young persons (e.g. Earle and Pauna, 1996).

As in the non-parametric analysis, the exit rate to employment increases with education, although only the coefficient on higher education is statistically significant: persons with completed higher education have the hazard rate of exit to employment which is $45 \%$ higher than the hazard rate for the individuals with primary or unfinished secondary education, ceteris paribus. This finding is in the conflict with the effect of education on exits from registered unemployment in Ukraine found by Stetsenko (2003). We attribute this discrepancy to the difference in the composition of vacancies notified at the public employment service and those advertised in the newspapers and private employment agencies in Ukraine with the former heavily represented by vacations for less-educated and less skilled persons (see Kuzmin et al. (2003) for details).

Our results support our hypothesis of no significant effect of receiving unemployment benefits implying that the existing unemployment benefit system is not contributing to longer unemployment 
spells. However, existence of other sources of subsistence during a period of unemployment such as income from casual work activities and subsidiary farming or household income or state transfers significantly lowers the probability of re-employment almost by the same amount. This result shows that such individuals are likely to search for regular jobs less intensively and that they have higher reservation wages and so are more selective in accepting job offers. However, a note of caution about state transfers is required here since its estimated effect on the exit rate from unemployment can inform about wrong policy decisions. The point is that in most presented models pension is combined with stipend and various kinds of social assistance in one category 'State transfers', but as has been discussed earlier it is preferable to control for behavior of unemployed pensioners separating them from the other recipients of state transfers. When we add two dummies 'Pension' and 'Other state transfers' instead of one dummy 'State transfers' to the model (Model 6), it appears that only the coefficient on 'Pension' is highly significant and larger by the magnitude while the coefficient on 'Other state transfers' is not significant. This finding shows that the behavior of unemployed pensioners on the labor market is really different from the behavior of their counterparts who do not receive pension. Returning to Boeri's hypothesis about the role of non-employment benefits for the outflows from unemployment (Boeri, 2001), we may conclude that unemployment benefits as well as social assistance measures are not significant determinants of unemployment duration in Ukraine.

Surprisingly, people relying on income from dividends, rents, interests, savings, etc. tend to have significantly shorter unemployment spells. The observed positive effect may be in part due to observed or unobserved characteristics which can explain stronger attachment of such individuals to the labor market (e.g. age, marital status, education, importance of employment status and fear of being unemployed and without money, etc.).

Previous wage incorporated in model (5) (Table 6a) seems to have no effect on unemployment duration, but we would not rely on these results that much since we have information on wages only for half of our sample. Moreover, it comes from the retrospective part and so is subject to significant reliability problem (Sudman and Bradburn, 1973).

Other surprising result from our study is that previous labor market state before unemployment (as well as a sector of previous employment and employment status) and previous unemployment experience do not alter the probability of leaving unemployment to jobs with the only exception of the experience of three or more prior unemployment spells the coefficient on which is positive and marginally significant at the $10 \%$ level. Our interpretation for this from the individuals' side is that individuals with many unemployment spells are more mobile on the labor market and can find the next job relatively easy, and that previously inactive persons have lower reservation wage that those previously employed. It is difficult to interpret these results from the employers' side, but we guess 
that employers use other information as a signal of worker's productivity and reliability but not his labor market history.

The local labor demand variables proxied in our model by the regional unemployment rate (oblastlevel quarterly registered unemployment rate in all models except Model (4) with yearly ILO-type unemployment rate) and the type of settlement have the expected signs. In model (3), the implied effect of a one percentage point increase in the registered unemployment rate is a 7.3 percent reduction in the hazard to job (response of the hazard to a one percentage increase in the ILO-type unemployment rate is about 3.6 percent decline). The residents of large cities (more than 500 thousands of inhabitants) have higher probabilities to leave unemployment for employment than those living in the rural area or very small towns. This suggests that local labor market conditions are important determinants of exit to jobs and that unemployment duration in a country might be lower if fewer barriers such as registration (just new name for the old system of propiska), high transportation and housing expenses existed for people to move to regions where labor market conditions were more favorable.

Finally, all specifications for the exits from unemployment to employment reveal that macroeconomic environment (proxied by the year of entering unemployment) and the starting season of unemployment seem to be not important for the determining unemployment duration before reemployment. Only those who became unemployed in 2002 have significantly higher hazards of exit to jobs compared to the reference group (those who entered unemployment in 1997). One potential explanation for non-response of the unemployment duration to economic growth in Ukraine is that there are serious barriers between unemployed and job opportunities (as has been discussed in the Introduction and Section 3) and that unemployment in Ukraine has at most structural character during the last years. Another potential explanation is that like in the CEE countries during the 90-s, employment growth in the old sector absorbs first of all 'hidden' unemployed who remain formally attached to a work place, while for the jobs created in the new sector unemployed have to compete with those still employed in the old sector (Blanchard, 1997).

When we turn to the multivariate analysis of the factors affecting exits from unemployment to economic inactivity (Table 6b), several primary results emerge. First, there is no significant difference by education, gender, marital and family status, regional unemployment rate, and previous unemployment experience.

Second, as we expected, younger workers have a significantly smaller hazard rate to inactivity than both prime-age or older individuals. This may be attributed to the fact that older persons are more inclined to retire and stop job search process, or that they can have some health problems or some other attributes that can lead to the smaller job search intensity or the loss of hope of finding a job (discouragement). 
Third, individuals entering unemployment after employment appear to search longer before withdrawing from the labor force than individuals being economically inactive before unemployment. The reason for this is perhaps higher importance of work and more negative reasons associated with not having a work and being idle for previously employed. Also they may anticipate their relative advantage in finding a job and so don't want to leave the labor market.

Fourth, we observe longer unemployment durations before withdrawing from the labor force for residents of small to medium towns compared to residents of rural area or very small towns, and no significant difference in unemployment durations between residents of cities and the latter. One of the possible explanations is that residents of rural area can at least move to self-employment (subsidiary agriculture) or leave the labor market in the case of unsuccessful search of 'paid' employment, while residents of small to medium towns stay unemployed longer hoping to find a regular job subject to the limited number of alternative activities.

Fifth, persons relying on household income and pension during unemployment are more likely to leave the labor force than persons without alternative income support since the former have less financial incentives to actively search for job and work at all. Significant effect of presence of income from casual work activities with respect to the exit to employment accompanied with its insignificant impact with respect to the exit to inactivity indicates that various casual work activities mainly in the informal sector and subsidiary farming can be considered as simply survival measures taken by those who would prefer the stability of a formal regular job but with a reasonable remuneration.

Finally, year and quarter coefficients imply that the hazard of exit from unemployment to inactivity increases with moving to the later year of starting unemployment and that those who enter unemployment in the second quarter tend to withdraw from the labor market faster than those who start unemployment in the first quarter, but we think that this result is more related to the disadvantages of retrospective data and classification errors rather than to some changes in macro environment inducing increased outflows to inactivity during the recent years.

Table $6 \mathrm{c}$ presents the value of the baseline hazard parameters defined in equation (*). Hazard to inactivity is rather smooth and very close to zero, while hazard to employment has several spikes and is relatively high after 4 years but few spells last sufficiently long to be affected by this sudden increase in the hazard. Furthermore, as Meyer (1990) concludes, "whatever the source of the spikes in the hazard, the baseline hazard parameters have identified an important feature of the data that would have been missed if a simple parametric baseline has been estimated. Anomalies in the hazard that remain after including covariates suggest variables to add or data problems to examine". And this will be the area for our further research.

\section{CONCLUSIONS}


This paper provides an empirical analysis of unemployment duration in Ukraine between 1997 and 2003 using a new rich nationally representative data set from the Ukrainian Longitudinal Monitoring Survey. Given the absence of an effective system of public employment services and unemployment insurance in Ukraine, this study tries to identify other potential determinants of unemployment duration.

We used semiparametric estimation techniques and compared it to alternative approaches. Our analysis has shown that there is huge heterogeneity among unemployed in the sample. Estimates from all specifications show that men do not appear to have significantly higher re-employment probabilities than women; married are more likely to leave unemployment to employment than not married persons while married women remain unemployed considerably longer than other groups; the older an individual the lower its probability of re-employment but the higher probability of exit to inactivity; unemployed with higher education tend to find jobs more quickly than individuals with unfinished secondary education; residents of large cities have higher exit rates to jobs than residents of rural area or small towns while residents of small to medium towns have lower exit rates to inactivity; the higher regional unemployment the lower the probability of re-employment; previous labor market history does not influence significantly the probability of re-employment, but previous labor market state seems to have significant effect on the probability of exit to inactivity. Additionally, individuals receiving unemployment benefits do not have significantly different durations with respect to exit to both destinations. Individuals who receive alternative income from casual work activities and subsidiary farming or rely on household income or pension remain unemployed considerably longer before finding a regular job. At the same time, pension and household income as the sources of subsistence encourage people to leave the labor force faster. Our results suggest that on average low non-employment benefits in Ukraine cannot be considered as the significant determinants of unemployment duration in contrast to the Boeri's hypothesis (Boeri, 2001). We unfortunately lack empirical evidence in order to judge for sure what factors are of the primary importance for explanation of stagnancy of unemployment in Ukraine but it seems that local demand constraints, measured by the regional unemployment rate and type of settlement, have the same or even lower importance now than the supply-side effects. Furthermore, according to our estimation results economic upturn in Ukraine during the last years appears to not influence the unemployment duration implying that a temporary shock in the early 90-s has brought long-lasting effects in terms of high and persistent unemployment and that unemployment in Ukraine during the last years can be characterized as mainly structural.

Unfortunately, we do not have necessary information to make a rigorous analysis of the effect of various features of the unemployment benefit system in Ukraine on the re-employment probabilities that can provide important policy implications. Also in spite of controlling for observed individual 
heterogeneity, we cannot be sure of the extent to which the pattern of duration dependence we have found (with an increase in the hazard during the first year, its slight decrease during the next three years followed by its gradual increase) reflects true duration dependence. For the moment, we would suggest that more attention should be paid to the exit rates corresponding to the several first months, since they are based on a more representative sample, but this issue certainly requires additional empirical assessment.

Based on our findings, we have the following policy recommendations:

- On the one hand, focus on employability of older individuals, and on the one hand, encourage withdrawal from the labor force among those entitled to any kind of pension. The second goal can be achieved by increasing the pension level to the subsistence minimum and by restricting the possibility of simultaneous receipt of pension benefits and full salary. The first group of measures may include: programs to retrain or upgrade skill levels for the unemployed with obsolete skills; measures to encourage employers to invest in on-the-job training of their employees; more intensive assistance with job search and measures to increase employer recruitment of older workers (e.g. recruitment subsidies, tax benefits, partial compensation for paid sick leave benefits, etc.); transition from the current practice of keeping records of years of service in a labor book towards a system of attaching information to an individual social insurance number.

- Give more attention to the quality of education and training programs rather than to the quantity of students. Educational policy should stress the significance of a broader-based curriculum and develop high-quality and widely marketable skills in order to improve the chance of smooth transition from studies to jobs. The risk of gross wastage of resources could be minimized by reaching agreements with employers who promise to hire students or trainees.

- Concentrate efforts on removing barriers to voluntary mobility, spreading more information about vacancies and living costs throughout the country, and developing the infrastructure, transport system and housing market (including development of mortgage loaning system). The Government should also encourage the creation of new jobs and the establishment of new firms in depressed areas through preferential credits and tax concessions, management training and business counseling, subsidies for research and development, access to new technologies, subsidies for human capital upgrading or retraining of permanent workers who are at risk of losing their jobs, assistance in marketing and sales, etc. A special focus should be also given to the programs to tackle rural long-term unemployment. Using modern communication technologies may help to minimize losses of time, associated with correspondence between local employment offices and the unemployed living in distant rural settlements.

- Pursue an economic and social policy which would encourage people to move from inefficient to efficient jobs, from informal activities towards the formal sector, and from unemployment to regular 
jobs. There is a need also for stricter monitoring of job searches among the registered unemployed and applying punitive measures to those who receive income from irregular work. These punitive measures could take the form of disqualification from unemployment benefits and any state-provided labor market program or complete removal from the unemployment register.

- Finally, simplify registration procedure, reduce transaction costs of staying at the registry, increase unemployment benefits to a reasonable level, and make measures provided by the employment centers more attractive in order to stimulate jobless individuals to register with the employment center. Another good motive for unemployed to register is to base the health care system on an insurance principle: compulsory health insurance contributions would be covered by the state only when people of working age are full-time students, disabled or registered jobseekers.

Although many of the suggested policies are subject to mere criticism because of their high costs, it is widely believed that they help to maintain the morale and social position of many long-term unemployed people what is very important for socially oriented states. 
Table 1. Duration of unemployment in Ukraine

\begin{tabular}{|c|c|c|c|c|}
\hline & 2000 & 2001 & 2002 & 2003 \\
\hline $\begin{array}{l}\text { Number of unemployed, who were searching for a job or were planning to start } \\
\text { business, thds. } \\
\text { Percentage of those searching for a job or planning to start business by duration } \\
\text { of their job search }\end{array}$ & 2628.7 & 2431.3 & 2204.3 & 1965.3 \\
\hline less than 1 month & 3.1 & 3.0 & 2.7 & 3.1 \\
\hline $1-3$ months & 10.1 & 11.0 & 12.4 & 13.8 \\
\hline 4-6 months & 11.0 & 11.0 & 11.6 & 12.8 \\
\hline 7-9 months & 12.2 & 10.1 & 10.0 & 10.5 \\
\hline $10-12$ months & 13.1 & 10.1 & 9.8 & 9.5 \\
\hline more than 12 months & 50.5 & 54.8 & 53.5 & 50.3 \\
\hline Average duration of job search, months & 10 & 10 & 10 & 9 \\
\hline Average duration of non-employment, months & 23 & 23 & 22 & 22 \\
\hline Average duration of registered unemployment, months & 11 & 9 & 8 & 7 \\
\hline
\end{tabular}

Source: Derzhkomstat, LFS (except for information on duration of registered unemployment)

Table 2. Main Labor Market Indicators in Ukraine: 1995-2003*

\begin{tabular}{|c|c|c|c|c|c|c|c|c|c|}
\hline & 1995 & 1996 & 1997 & 1998 & 1999 & 2000 & 2001 & 2002 & 2003 \\
\hline $\begin{array}{l}\text { Registered } \\
\text { unemployment } \\
\text { Number of registered } \\
\text { unemployed, thds. }\end{array}$ & 126.9 & 351.1 & 637.1 & 1003.2 & 1174.5 & 1155.2 & 1008.1 & 1034.2 & 988.9 \\
\hline $\begin{array}{l}\text { Registered unemployment } \\
\text { rate, } \% \text { of working-age } \\
\text { able-bodied population }\end{array}$ & 0.46 & 1.27 & 2.33 & 3.69 & 4.3 & 4.22 & 3.68 & 3.80 & 3.6 \\
\hline $\begin{array}{l}\text { Fraction of registered } \\
\text { unemployed receiving } \\
\text { unemployment benefits, } \\
\%\end{array}$ & 57.4 & 61.1 & 56.8 & 53.1 & 52.8 & 54.3 & 62 & 66.7 & 69.1 \\
\hline $\begin{array}{l}\text { ILO-defined } \\
\text { unemployment } \\
\text { Number of unemployed } \\
\text { according to LFS, thds. }\end{array}$ & 1437.0 & 1997.5 & 2330.1 & 2937.1 & 2698.8 & 2707.6 & 2516.9 & 2301.0 & 2059.5 \\
\hline $\begin{array}{l}\text { Unemployment rate } \\
\text { according to LFS, } \\
\% \text { of labor force aged } \\
\text { from } 15 \text { to } 70\end{array}$ & 5.6 & 7.6 & 8.9 & 11.3 & 11.9 & 11.7 & 11.1 & 10.1 & 9.1 \\
\hline $\begin{array}{l}\text { Employment } \\
\text { Number of employed } \\
\text { according to LFS, thds. }\end{array}$ & 24125.1 & 24114.0 & 23755.5 & 22998.4 & 20048.2 & 20419.8 & 20238.1 & 20400.7 & 20554.7 \\
\hline $\begin{array}{l}\text { Employment rate } \\
\text { according to LFS, } \\
\% \text { of population aged } \\
\text { from } 15 \text { to } 70 \\
\end{array}$ & 64 & 64 & 64.5 & 62.8 & 54.9 & 56.1 & 55.8 & 56.2 & 56.6 \\
\hline $\begin{array}{l}\text { Labor Force and } \\
\text { Population } \\
\text { Labor Force, thds. }\end{array}$ & 25562.1 & 26111.5 & 26085.6 & 25935.5 & 22747.0 & 23127.4 & 22755.0 & 22701.7 & 22614.2 \\
\hline $\begin{array}{l}\text { Labor Force Participation } \\
\text { Rate, \% of population } \\
\text { aged from } 15 \text { to } 70\end{array}$ & 67.85 & 69.31 & 70.81 & 70.77 & 62.27 & 63.53 & 62.71 & 62.57 & 62.33 \\
\hline Population, thds. & 51297.1 & 50818.4 & 50370.8 & 49918.1 & 49429.8 & 48923.2 & 48457.1 & 48003.5 & 47580 \\
\hline $\begin{array}{l}\text { Wages and UB } \\
\text { Average nominal wage, } \\
\text { UHA }\end{array}$ & 73 & 126 & 143 & 153 & 178 & 230 & 311 & 376 & 462 \\
\hline $\begin{array}{l}\text { Average unemployment } \\
\text { benefits, UHA }\end{array}$ & NA & NA & NA & 38.5 & 49.8 & 59.39 & 85.23 & 105.98 & 118.32 \\
\hline $\begin{array}{l}\text { Ratio of average } \\
\text { unemployment benefits to } \\
\text { minimum wage, } \%\end{array}$ & NA & NA & NA & 70 & 67.3 & 50.3 & 72.2 & 64.2 & 57.7 \\
\hline
\end{tabular}




\begin{tabular}{|l|c|c|c|c|c|c|c|c|}
\hline $\begin{array}{l}\text { Ratio of average } \\
\text { unemployment benefits to } \\
\text { average wage, } \%\end{array}$ & NA & NA & NA & 25.1 & 28 & 25.8 & 27.4 & 28.1 \\
\hline
\end{tabular}

Note: *Registered unemployment characteristics correspond to the end of years, while characteristics according to the LFSs are presented for the fourth quarters in 1995-1998 (yearly surveys) and on average for 1999-2003 (quarterly surveys). Source: Derzhkomstat (Ukraine's State Committee of Statistics)

Table 3. Job search strategies of the unemployed in 1997-2003 (\% to all responses)

\begin{tabular}{|l|c|}
\hline Asked relatives or friends & 29.55 \\
\hline Responded to job advertisements & 18.09 \\
\hline Placed job advertisements & 1.93 \\
\hline Watched job advertisements & 17.93 \\
\hline Contacted employers directly & 16.06 \\
\hline Went to a job interview, took an exam or a test & 1.83 \\
\hline Sought job through the State Employment Service & 10.53 \\
\hline Sought job through private employment agency & 1.59 \\
\hline Applied to register own enterprise/farm, for activity license or loan & 0.32 \\
\hline $\begin{array}{l}\text { Sought for land, rooms, equipment, employees, etc. to start an } \\
\text { enterprise/farm }\end{array}$ & 0.09 \\
\hline Waited for an answer to a job application & 0.59 \\
\hline Waited for an answer from the State Employment Service & 1.41 \\
\hline Waited for an earlier contracted job to start & 0.07 \\
\hline \hline Number of observations (unemployment spells) & 2122 \\
\hline Number of responses & 5584 \\
\hline
\end{tabular}

Source: ULMS-2003, our sample, author's calculations

Table 4. Main sources of subsistence during a period of unemployment in Ukraine: 1997-2003

\begin{tabular}{|l|c|c|}
\hline Source of Subsistence & Frequency & $\%$ \\
\hline \hline Unemployment benefits & 96 & 4.52 \\
\hline Income from casual work & 147 & 6.93 \\
Income from sale of products from own land plot & 64 & 3.02 \\
Income from casual business activities & 28 & 1.32 \\
Subsidiary farming for own needs & 51 & 2.4 \\
Total for Casual Work & 290 & 13.67 \\
\hline Income of spouse & 608 & 28.65 \\
Income of parents & 659 & 31.06 \\
Support from relatives & 190 & 8.95 \\
Total for Household Income & 1457 & 68.66 \\
\hline Pension & 137 & 6.46 \\
Child allowance & 12 & 0.57 \\
Alimony & 6 & 0.28 \\
Social benefits, subsistence allowance & 12 & 0.57 \\
Supported by state or municipal institution & 15 & 0.71 \\
Total for State Transfers & 182 & 8.59 \\
\hline Sale of property & 4 & 0.19 \\
Income from rent, interests, dividends & 3 & 0.14 \\
Loans & 2 & 0.09 \\
Savings & 62 & 2.92 \\
Total for Other Sources of Subsistence & 71 & 3.34 \\
\hline Number of observations & 2122 & 100 \\
\hline
\end{tabular}

Source: ULMS-2003, our sample, author's calculations 
Table 5. Descriptive statistics

\begin{tabular}{|c|c|c|c|c|}
\hline Variable & Mean & Std. Dev. & Min & Max \\
\hline Exit to Employment & 0.517 & 0.500 & 0 & 1 \\
\hline Exit to Inactivity & 0.173 & 0.379 & 0 & 1 \\
\hline Censored & 0.308 & 0.462 & 0 & 1 \\
\hline Discrete duration & 17.17 & 15.89 & 1 & 66 \\
\hline \multicolumn{5}{|l|}{ Duration group (total sample, $\mathrm{N}=2122$ ) } \\
\hline$<1$ month & 0.024 & 0.153 & 0 & 1 \\
\hline 1-3 months & 0.159 & 0.366 & 0 & 1 \\
\hline 4-6 months & 0.159 & 0.365 & 0 & 1 \\
\hline 7-9 months & 0.101 & 0.299 & 0 & 1 \\
\hline $10-12$ months & 0.914 & 0.293 & 0 & 1 \\
\hline$>12$ months & 0.465 & 0.499 & 0 & 1 \\
\hline \multicolumn{5}{|l|}{ Duration group (censored spells, $\mathrm{N}=654$ ) } \\
\hline$<1$ month & 0.041 & 0.199 & 0 & 1 \\
\hline 1-3 months & 0.136 & 0.343 & 0 & 1 \\
\hline 4-6 months & 0.156 & 0.363 & 0 & 1 \\
\hline 7-9 months & 0.098 & 0.293 & 0 & 1 \\
\hline $10-12$ months & 0.087 & 0.287 & 0 & 1 \\
\hline$>12$ months & 0.482 & 0.500 & 0 & 1 \\
\hline Female & 0.508 & 0.500 & 0 & 1 \\
\hline Married & 0.555 & 0.497 & 0 & 1 \\
\hline Female*Married & 0.292 & 0.455 & 0 & 1 \\
\hline Presence of children up to 15 years old & 0.487 & 0.500 & 0 & 1 \\
\hline Number of Children up to 15 years old & 0.686 & 0.833 & 0 & 4 \\
\hline Female*Number of Children up to 15 years old & 0.384 & 0.711 & 0 & 4 \\
\hline \multicolumn{5}{|l|}{ Age group } \\
\hline$\leq 24$ & 0.334 & 0.472 & 0 & 1 \\
\hline $25-39$ & 0.341 & 0.474 & 0 & 1 \\
\hline $40-54$ & 0.284 & 0.451 & 0 & 1 \\
\hline$\geq 55$ & 0.041 & 0.199 & 0 & 1 \\
\hline Age & 32.971 & 12.206 & 15 & 67 \\
\hline \multicolumn{5}{|l|}{ Education } \\
\hline Primary or unfinished secondary & 0.140 & 0.347 & 0 & 1 \\
\hline General secondary or vocational & 0.511 & 0.500 & 0 & 1 \\
\hline Professional secondary or unfinished higher & 0.225 & 0.418 & 0 & 1 \\
\hline Higher & 0.123 & 0.329 & 0 & 1 \\
\hline \multicolumn{5}{|l|}{ Sources of subsistence } \\
\hline Unemployment Benefits or Stipend during Training & 0.180 & 0.384 & 0 & 1 \\
\hline Casual Work & 0.281 & 0.450 & 0 & 1 \\
\hline Income from casual work & 0.165 & 0.371 & 0 & 1 \\
\hline Income from sale of products from own land plot & 0.069 & 0.253 & 0 & 1 \\
\hline Income from casual business activities & 0.028 & 0.166 & 0 & 1 \\
\hline Subsidiary farming for own needs & 0.048 & 0.213 & 0 & 1 \\
\hline Household Income & 0.808 & 0.394 & 0 & 1 \\
\hline Income of spouse & 0.371 & 0.483 & 0 & 1 \\
\hline Income of parents & 0.401 & 0.490 & 0 & 1 \\
\hline Support from relatives & 0.200 & 0.400 & 0 & 1 \\
\hline State Transfers & 0.201 & 0.401 & 0 & 1 \\
\hline Pension & 0.092 & 0.289 & 0 & 1 \\
\hline Stipend or study loan & 0.026 & 0.160 & 0 & 1 \\
\hline Other SS & 0.061 & 0.239 & 0 & 1 \\
\hline Savings & 0.050 & 0.219 & 0 & 1 \\
\hline Loans & 0.009 & 0.942 & 0 & 1 \\
\hline
\end{tabular}


Table 5. Descriptive statistics (cont.)

\begin{tabular}{|c|c|c|c|c|}
\hline Variable & Mean & Std. Dev. & Min & Max \\
\hline \multicolumn{5}{|l|}{ Previous state } \\
\hline Inactive & 0.424 & 0.494 & 0 & 1 \\
\hline Employee & 0.544 & 0.498 & 0 & 1 \\
\hline Self-employed, employer, or entrepreneur & 0.023 & 0.149 & 0 & 1 \\
\hline Member of cooperative & 0.010 & 0.099 & 0 & 1 \\
\hline \multicolumn{5}{|l|}{ Sector of previous employment $(\mathrm{N}=1210)$} \\
\hline Agriculture & 0.133 & 0.340 & 0 & 1 \\
\hline Manufacturing \& Mining & 0.281 & 0.450 & 0 & 1 \\
\hline Electricity, gas and water supply & 0.013 & 0.114 & 0 & 1 \\
\hline Construction & 0.088 & 0.284 & 0 & 1 \\
\hline Trade, hotels and restaurants & 0.183 & 0.387 & 0 & 1 \\
\hline Transport, storage and communication & 0.065 & 0.247 & 0 & 1 \\
\hline Financial, real estate, renting and business activities & 0.026 & 0.161 & 0 & 1 \\
\hline Public administration and defense & 0.031 & 0.174 & 0 & 1 \\
\hline Education, health and social work & 0.084 & 0.278 & 0 & 1 \\
\hline Other community, social and personal service activities & 0.088 & 0.284 & 0 & 1 \\
\hline Other activities & 0.006 & 0.076 & 0 & 1 \\
\hline \multicolumn{5}{|l|}{ Year of entering unemployment } \\
\hline 1997 & 0.161 & 0.368 & 0 & 1 \\
\hline 1998 & 0.136 & 0.343 & 0 & 1 \\
\hline 1999 & 0.130 & 0.336 & 0 & 1 \\
\hline 2000 & 0.139 & 0.347 & 0 & 1 \\
\hline 2001 & 0.131 & 0.338 & 0 & 1 \\
\hline 2002 & 0.187 & 0.390 & 0 & 1 \\
\hline 2003 & 0.115 & 0.319 & 0 & 1 \\
\hline \multicolumn{5}{|l|}{ Quarter of entering unemployment } \\
\hline I & 0.242 & 0.429 & 0 & 1 \\
\hline II & 0.238 & 0.426 & 0 & 1 \\
\hline III & 0.191 & 0.393 & 0 & 1 \\
\hline IV & 0.329 & 0.470 & 0 & 1 \\
\hline \multicolumn{5}{|l|}{ Type of settlement } \\
\hline Village or small town (less than 20 thds. inhabitants) & 0.456 & 0.498 & 0 & 1 \\
\hline Town (from 20 to 500 thds.) & 0.320 & 0.467 & 0 & 1 \\
\hline Large city (more than 500 thds.) & 0.223 & 0.417 & 0 & 1 \\
\hline \multicolumn{5}{|l|}{ Local labor market characteristics ${ }^{\mathrm{c}}$} \\
\hline Regional Registered Unemployment Rate & 3.639 & 1.658 & 0.47 & 8.09 \\
\hline Number of Registered Unemployed per Vacancy & 20.825 & 24.859 & 0.53 & 324.55 \\
\hline \multicolumn{5}{|l|}{ Previous unemployment } \\
\hline No previous unemployment & 0.848 & 0.359 & 0 & 1 \\
\hline One prior unemployment spell & 0.130 & 0.336 & 0 & 1 \\
\hline Two prior unemployment spells & 0.018 & 0.133 & 0 & 1 \\
\hline Three and more prior unemployment spells & 0.005 & 0.069 & 0 & 1 \\
\hline
\end{tabular}

Note: $\mathrm{N}=2122$. Variables are measured at the beginning of the unemployment spell except for the local labor market characteristics which are measured at the end of the quarter corresponding to the starting date of the unemployment spell. 
Table 6a. Duration Analysis of Exits from Unemployment in Ukraine - Exits to Employment, all unemployment spells

\begin{tabular}{|c|c|c|c|c|c|c|}
\hline \multirow[t]{2}{*}{ Variable } & \multicolumn{2}{|c|}{ Cox PH } & \multicolumn{2}{|c|}{$\begin{array}{l}\text { Cloglog with cubic } \\
\text { polynomial baseline }\end{array}$} & \multicolumn{2}{|c|}{$\begin{array}{c}\text { Cloglog with } \\
\text { nonparametric baseline }\end{array}$} \\
\hline & \multicolumn{2}{|c|}{ (1) } & \multicolumn{2}{|c|}{ (2) } & \multicolumn{2}{|c|}{$(3)^{\#}$} \\
\hline Female & -0.084 & $(0.095)$ & -0.080 & $(0.096)$ & -0.087 & $(0.096)$ \\
\hline Married & $0.295 * *$ & $(0.104)$ & $0.304 * *$ & $(0.104)$ & $0.297 * *$ & $(0.104)$ \\
\hline Female* Married & $-0.294 *$ & $(0.134)$ & $-0.301 *$ & $(0.134)$ & $-0.292 *$ & $(0.134)$ \\
\hline Number of children & -0.079 & $(0.066)$ & -0.079 & $(0.066)$ & -0.078 & $(0.066)$ \\
\hline Female* children & 0.109 & $(0.084)$ & 0.107 & $(0.084)$ & 0.107 & $(0.084)$ \\
\hline \multicolumn{7}{|l|}{ Age } \\
\hline $25-39$ & $-0.413 * *$ & $(0.089)$ & $-0.417 * *$ & $(0.089)$ & $-0.419 * *$ & $(0.089)$ \\
\hline $40-54$ & $-0.617 * *$ & $(0.097)$ & $-0.626 * *$ & $(0.097)$ & $-0.627 * *$ & $(0.097)$ \\
\hline$\geq 55$ & $-1.116^{* *}$ & $(0.213)$ & $-1.126^{* *}$ & $(0.215)$ & $-1.123 * *$ & $(0.215)$ \\
\hline \multicolumn{7}{|l|}{ Education } \\
\hline $\begin{array}{r}\text { General secondary or } \\
\text { vocational }\end{array}$ & 0.057 & $(0.094)$ & 0.047 & $(0.093)$ & 0.047 & $(0.094)$ \\
\hline $\begin{array}{r}\text { Professional secondary or } \\
\text { unfinished higher }\end{array}$ & 0.142 & $(0.107)$ & 0.136 & $(0.107)$ & 0.139 & $(0.107)$ \\
\hline Higher & $0.379 * *$ & $(0.123)$ & $0.372 * *$ & $(0.123)$ & $0.375 * *$ & $(0.124)$ \\
\hline \multicolumn{7}{|l|}{ Sources of Subsistence } \\
\hline Unemployment Benefits & 0.030 & $(0.079)$ & 0.031 & $(0.080)$ & 0.029 & $(0.080)$ \\
\hline Casual Work & $-0.276 * *$ & $(0.075)$ & $-0.265 * *$ & $(0.075)$ & $-0.269 * *$ & $(0.075)$ \\
\hline Household Income & $-0.250 * *$ & $(0.090)$ & $-0.244 * *$ & $(0.090)$ & $-0.249 * *$ & $(0.091)$ \\
\hline State Transfers & $-0.280 * *$ & $(0.087)$ & $-0.279 * *$ & $(0.088)$ & $-0.276^{* *}$ & $(0.088)$ \\
\hline Other SS & $0.336^{* *}$ & $(0.144)$ & $0.317^{*}$ & $(0.145)$ & $0.329 *$ & $(0.145)$ \\
\hline Regional UR ${ }^{\# \#}$ & $-0.073 * *$ & $(0.023)$ & $-0.072 * *$ & $(0.023)$ & $-0.073 * *$ & $(0.023)$ \\
\hline \multicolumn{7}{|l|}{ Type of settlement } \\
\hline Town & 0.083 & $(0.072)$ & 0.087 & $(0.073)$ & 0.086 & $(0.073)$ \\
\hline Large city & $0.262 * *$ & $(0.091)$ & $0.269 * *$ & $(0.091)$ & $0.267 * *$ & $(0.091)$ \\
\hline \multicolumn{7}{|l|}{ Previous unemployment } \\
\hline 1 prior spell & 0.105 & $(0.106)$ & 0.114 & $(0.107)$ & 0.110 & $(0.107)$ \\
\hline 2 prior spells & -0.099 & $(0.341)$ & -0.124 & $(0.344)$ & -0.127 & $(0.343)$ \\
\hline 3 or more prior spells & 0.614 & $(0.346)$ & 0.615 & $(0.350)$ & 0.618 & $(0.367)$ \\
\hline Previously employed & -0.096 & $(0.082)$ & -0.108 & $(0.082)$ & -0.103 & $(0.082)$ \\
\hline \multicolumn{7}{|l|}{ Year } \\
\hline 1998 & -0.066 & $(0.129)$ & -0.090 & $(0.129)$ & -0.100 & $(0.129)$ \\
\hline 1999 & 0.124 & $(0.133)$ & 0.123 & $(0.134)$ & 0.102 & $(0.134)$ \\
\hline 2000 & 0.195 & $(0.133)$ & 0.169 & $(0.133)$ & 0.165 & $(0.133)$ \\
\hline 2001 & 0.241 & $(0.142)$ & 0.203 & $(0.143)$ & 0.198 & $(0.143)$ \\
\hline 2002 & $0.388^{* *}$ & $(0.148)$ & $0.328^{*}$ & $(0.150)$ & $0.298^{*}$ & $(0.149)$ \\
\hline 2003 & 0.454 & $(0.259)$ & 0.034 & $(0.251)$ & 0.038 & $(0.255)$ \\
\hline \multicolumn{7}{|l|}{ Quarter } \\
\hline II & -0.105 & $(0.107)$ & -0.132 & $(0.107)$ & -0.114 & $(0.107)$ \\
\hline III & -0.057 & $(0.100)$ & -0.069 & $(0.100)$ & -0.058 & $(0.100)$ \\
\hline IV & 0.090 & $(0.106)$ & 0.080 & $(0.106)$ & 0.079 & $(0.107)$ \\
\hline duration & - & & -0.004 & $(0.014)$ & - & \\
\hline duration $^{2}$ & - & & -0.001 & $(0.001)$ & - & \\
\hline duration $^{3}$ & - & & $0.000 * *$ & $(0.000)$ & - & \\
\hline constant & - & & $-2.698 * *$ & $(0.220)$ & - & \\
\hline $\mathrm{N}$ & \multirow{2}{*}{\multicolumn{2}{|c|}{$\begin{array}{l}2122 \text { spells } \\
-7347.208\end{array}$}} & \multirow{2}{*}{\multicolumn{2}{|c|}{$\begin{array}{c}36429 \text { spell-months } \\
-4809.117\end{array}$}} & \multirow{2}{*}{\multicolumn{2}{|c|}{$\begin{array}{c}36397 \text { spell-months } \\
-4736.961\end{array}$}} \\
\hline Log-likelihood & & & & & & \\
\hline
\end{tabular}


Table 6a. Duration Analysis of Exits from Unemployment in Ukraine - Exits to Employment, all unemployment spells (cont.)

\begin{tabular}{|c|c|c|c|c|c|c|}
\hline \multirow{2}{*}{ Variable } & \multicolumn{6}{|c|}{ Cloglog with nonparametric baseline } \\
\hline & \multicolumn{2}{|c|}{ (4) } & \multicolumn{2}{|c|}{ (5) } & \multicolumn{2}{|c|}{ (6) } \\
\hline Female & -0.100 & $(0.097)$ & 0.063 & $(0.167)$ & -0.081 & $(0.096)$ \\
\hline Married & $0.290 * *$ & $(0.105)$ & 0.215 & $(0.162)$ & $0.304 * *$ & $(0.104)$ \\
\hline Female* Married & $-0.295 *$ & $(0.135)$ & $-0.469 *$ & $(0.212)$ & $-0.300 *$ & $(0.134)$ \\
\hline Number of children & -0.096 & $(0.067)$ & -0.032 & $(0.109)$ & -0.081 & $(0.066)$ \\
\hline Female* children & 0.130 & $(0.085)$ & 0.116 & $(0.134)$ & 0.091 & $(0.085)$ \\
\hline \multicolumn{7}{|l|}{ Age } \\
\hline $25-39$ & $-0.399 * *$ & $(0.089)$ & $-0.445 * *$ & $(0.141)$ & $-0.400 * *$ & $(0.090)$ \\
\hline $40-54$ & $-0.610 * *$ & $(0.098)$ & $-0.682 * *$ & $(0.145)$ & $-0.586^{* *}$ & $(0.099)$ \\
\hline$\geq 55$ & $-1.094 * *$ & $(0.213)$ & $-0.982 * *$ & $(0.313)$ & $-0.952 * *$ & $(0.225)$ \\
\hline \multicolumn{7}{|l|}{ Education } \\
\hline $\begin{array}{r}\text { General secondary or } \\
\text { vocational }\end{array}$ & 0.030 & $(0.094)$ & -0.080 & $(0.154)$ & 0.060 & $(0.093)$ \\
\hline $\begin{array}{r}\text { Professional secondary or } \\
\text { unfinished higher }\end{array}$ & 0.131 & $(0.107)$ & 0.127 & $(0.165)$ & 0.153 & $(0.107)$ \\
\hline Higher & $0.373 * *$ & $(0.124)$ & $0.421 * *$ & $(0.181)$ & $0.376^{* *}$ & $(0.123)$ \\
\hline \multicolumn{7}{|l|}{ Sources of Subsistence } \\
\hline Unemployment benefits & 0.013 & $(0.080)$ & -0.091 & $(0.115)$ & 0.017 & $(0.080)$ \\
\hline Casual Work & $-0.266 * *$ & $(0.075)$ & -0.196 & $(0.112)$ & $-0.292 * *$ & $(0.076)$ \\
\hline Household Income & $-0.247 * *$ & $(0.091)$ & $-0.320 *$ & $(0.128)$ & $-0.294 * *$ & $(0.091)$ \\
\hline State Transfers & $-0.287 * *$ & $(0.087)$ & $-0.454 * *$ & $(0.141)$ & & \\
\hline Pension & - & & - & & $-0.553 * *$ & $(0.140)$ \\
\hline Other state transfers & - & & - & & -0.105 & $(0.104)$ \\
\hline Other SS & $0.337 *$ & $(0.144)$ & 0.288 & $(0.196)$ & $0.315^{*}$ & $(0.145)$ \\
\hline Regional UR ${ }^{\# \#}$ & $-0.036^{* *}$ & $(0.014)$ & $-0.083^{*}$ & $(0.037)$ & $-0.077 * *$ & $(0.023)$ \\
\hline \multicolumn{7}{|l|}{ Type of settlement } \\
\hline Town & 0.083 & $(0.074)$ & 0.163 & $(0.117)$ & 0.094 & $(0.073)$ \\
\hline Large city & $0.360 * *$ & $(0.084)$ & $0.400 * *$ & $(0.144)$ & $0.269^{* *}$ & $(0.091)$ \\
\hline \multicolumn{7}{|l|}{ Previous unemployment } \\
\hline 1 prior spell & 0.122 & $(0.107)$ & -0.026 & $(0.136)$ & 0.123 & $(0.108)$ \\
\hline 2 prior spells & -0.105 & $(0.339)$ & -0.543 & $(0.482)$ & -0.102 & $(0.346)$ \\
\hline 3 or more prior spells & 0.582 & $(0.367)$ & $0.612 * *$ & $(0.193)$ & 0.610 & $(0.345)$ \\
\hline Previously employed & -0.098 & $(0.082)$ & -0.099 & $(0.207)$ & -0.108 & $(0.083)$ \\
\hline Log $(\text { Real Last Wage })^{\mathrm{g}}$ & - & & -0.027 & $(0.070)$ & - & \\
\hline $\mathrm{N}$ & \multirow{2}{*}{\multicolumn{2}{|c|}{$\begin{array}{c}36397 \text { spell-months } \\
-4738.794\end{array}$}} & \multirow{2}{*}{\multicolumn{2}{|c|}{$\begin{array}{l}17611 \text { spell-months } \\
-2138.306\end{array}$}} & \multirow{2}{*}{\multicolumn{2}{|c|}{$\begin{array}{c}36397 \text { spell-months } \\
-4733.626\end{array}$}} \\
\hline Log-likelihood & & & & & & \\
\hline
\end{tabular}

Note: Number of failures is 1099. Figures reported are the estimated coefficients. Robust standard errors adjusted for clustering on individual identifier in parentheses. ${ }^{* *}$ and $*$ denote significance at the $1 \%$ and $5 \%$ levels, respectively. ${ }^{\#}$ Baseline hazard parameters are reported in Table 6c. All models include year and quarter dummies. ${ }^{\#}$ Registered unemployment rate for 24 oblasts, Crimean Republic and Kiev City in specifications (1)-(3), (5)-(6) and ILO-type unemployment rate in specification (4). Exits to inactivity are considered censored when estimating exits to employment, and vice versa. 
Table 6b. Duration Analysis of Exits from Unemployment in Ukraine - Exits to Inactivity, all unemployment spells

\begin{tabular}{|c|c|c|c|c|c|c|}
\hline \multirow[t]{2}{*}{ Variable } & \multicolumn{2}{|c|}{ Cox PH } & \multicolumn{2}{|c|}{$\begin{array}{l}\text { Cloglog with cubic } \\
\text { polynomial baseline }\end{array}$} & \multicolumn{2}{|c|}{$\begin{array}{c}\text { Cloglog with } \\
\text { nonparametric baseline }\end{array}$} \\
\hline & \multicolumn{2}{|c|}{ (1) } & \multicolumn{2}{|c|}{$(2)$} & \multicolumn{2}{|c|}{$(3)^{\#}$} \\
\hline Female & 0.138 & $(0.179)$ & 0.158 & $(0.181)$ & 0.151 & $(0.182)$ \\
\hline Married & -0.023 & $(0.194)$ & 0.008 & $(0.197)$ & 0.001 & $(0.196)$ \\
\hline Female* Married & 0.037 & $(0.238)$ & 0.016 & $(0.241)$ & 0.024 & $(0.241)$ \\
\hline Number of children & -0.275 & $(0.145)$ & -0.274 & $(0.146)$ & -0.274 & $(0.146)$ \\
\hline Female* children & 0.213 & $(0.167)$ & 0.217 & $(0.169)$ & 0.217 & $(0.168)$ \\
\hline \multicolumn{7}{|l|}{ Age } \\
\hline $25-39$ & -0.057 & $(0.173)$ & -0.068 & $(0.173)$ & -0.071 & $(0.173)$ \\
\hline $40-54$ & $0.505 * *$ & $(0.165)$ & $0.486^{* *}$ & $(0.166)$ & $0.491 * *$ & $(0.167)$ \\
\hline$\geq 55$ & $1.137 * *$ & $(0.236)$ & $1.141^{* *}$ & $(0.237)$ & $1.137 * *$ & $(0.237)$ \\
\hline \multicolumn{7}{|l|}{ Education } \\
\hline $\begin{array}{r}\text { General secondary or } \\
\text { vocational }\end{array}$ & 0.056 & $(0.155)$ & 0.040 & $(0.157)$ & 0.046 & $(0.157)$ \\
\hline $\begin{array}{r}\text { Professional secondary or } \\
\text { unfinished higher }\end{array}$ & 0.154 & $(0.166)$ & 0.128 & $(0.168)$ & 0.146 & $(0.168)$ \\
\hline Higher & 0.023 & $(0.211)$ & -0.003 & $(0.212)$ & 0.009 & $(0.212)$ \\
\hline \multicolumn{7}{|l|}{ Sources of Subsistence } \\
\hline Unemployment benefits & 0.124 & $(0.142)$ & 0.147 & $(0.144)$ & 0.131 & $(0.144)$ \\
\hline Casual Work & 0.149 & $(0.122)$ & 0.159 & $(0.122)$ & 0.156 & $(0.123)$ \\
\hline Household Income & $0.359 *$ & $(0.149)$ & $0.365^{*}$ & $(0.151)$ & $0.360^{*}$ & $(0.152)$ \\
\hline StateTransfers & 0.194 & $(0.135)$ & 0.215 & $(0.136)$ & 0.209 & $(0.137)$ \\
\hline Other SS & -0.174 & $(0.292)$ & -0.184 & $(0.294)$ & -0.182 & $(0.292)$ \\
\hline Regional UR \#\# & -0.055 & $(0.037)$ & -0.051 & $(0.037)$ & -0.054 & $(0.037)$ \\
\hline \multicolumn{7}{|l|}{ Type of settlement } \\
\hline Town & $-0.347 * *$ & $(0.131)$ & $-0.352 * *$ & $(0.132)$ & $-0.345 * *$ & $(0.132)$ \\
\hline Large city & -0.255 & $(0.172)$ & -0.254 & $(0.172)$ & -0.256 & $(0.173)$ \\
\hline \multicolumn{7}{|l|}{ Previous unemployment } \\
\hline 1 prior spell & 0.067 & $(0.197)$ & 0.086 & $(0.199)$ & 0.081 & $(0.200)$ \\
\hline 2 prior spells & 0.383 & $(0.515)$ & 0.329 & $(0.510)$ & 0.312 & $(0.521)$ \\
\hline 3 or more prior spells & 1.018 & $(0.799)$ & 0.917 & $(0.839)$ & 0.996 & $(0.844)$ \\
\hline Previously employed & $-0.589 * *$ & $(0.134)$ & $-0.597 * *$ & $(0.136)$ & $-0.597 * *$ & $(0.137)$ \\
\hline \multicolumn{7}{|l|}{ Year } \\
\hline 1998 & $0.530^{*}$ & $(0.234)$ & $0.515^{*}$ & $(0.236)$ & $0.501^{*}$ & $(0.236)$ \\
\hline 1999 & $0.848 * *$ & $(0.260)$ & $0.831 * *$ & $(0.262)$ & $0.812 * *$ & $(0.262)$ \\
\hline 2000 & $1.087 * *$ & $(0.257)$ & $1.026 * *$ & $(0.257)$ & $1.029 * *$ & $(0.257)$ \\
\hline 2001 & $1.315^{* *}$ & $(0.293)$ & $1.216^{* *}$ & $(0.293)$ & $1.240 * *$ & $(0.291)$ \\
\hline 2002 & $2.076^{* *}$ & $(0.320)$ & $2.017^{* *}$ & $(0.313)$ & $1.920 * *$ & $(0.313)$ \\
\hline 2003 & $3.674 * *$ & $(0.417)$ & $2.970 * *$ & $(0.392)$ & $3.120 * *$ & $(0.399)$ \\
\hline \multicolumn{7}{|l|}{ Quarter } \\
\hline II & $0.421^{*}$ & $(0.169)$ & 0.295 & $(0.160)$ & $0.348^{*}$ & $(0.165)$ \\
\hline III & 0.277 & $(0.181)$ & 0.165 & $(0.175)$ & 0.236 & $(0.178)$ \\
\hline IV & $0.398^{*}$ & $(0.193)$ & 0.309 & $(0.187)$ & 0.343 & $(0.190)$ \\
\hline duration & - & & $0.104 * *$ & $(0.028)$ & - & \\
\hline duration $^{2}$ & - & & $-0.003 * *$ & $(0.001)$ & - & \\
\hline duration $^{3}$ & - & & $0.000 * *$ & $(0.000)$ & - & \\
\hline constant & - & & $-6.675 * *$ & $(0.444)$ & - & \\
\hline $\begin{array}{l}\mathrm{N} \\
\text { Log-likelihood }\end{array}$ & $\begin{array}{l}212 \\
-22 \\
\end{array}$ & & $\begin{array}{r}36429 \mathrm{~s} 1 \\
-19\end{array}$ & $\begin{array}{l}\text { months } \\
54\end{array}$ & $\begin{array}{r}35838 \mathrm{~s} \\
-18\end{array}$ & $\begin{array}{l}\text { months } \\
57\end{array}$ \\
\hline
\end{tabular}


Table 6b. Duration Analysis of Exits from Unemployment in Ukraine - Exits to Inactivity, all unemployment spells (cont.)

\begin{tabular}{|c|c|c|c|c|}
\hline \multirow{2}{*}{ Variable } & \multicolumn{4}{|c|}{ Cloglog with nonparametric baseline } \\
\hline & \multicolumn{2}{|c|}{ (4) } & \multicolumn{2}{|c|}{ (5) } \\
\hline Female & 0.146 & $(0.182)$ & 0.141 & $(0.181)$ \\
\hline Married & 0.004 & $(0.196)$ & -0.005 & $0.196)$ \\
\hline Female* Married & 0.016 & $(0.241)$ & 0.029 & $(0.241)$ \\
\hline Number of children & -0.287 & $(0.145)$ & -0.275 & $(0.146)$ \\
\hline Female* children & 0.236 & $(0.167)$ & 0.237 & $(0.169)$ \\
\hline \multicolumn{5}{|l|}{ Age } \\
\hline $25-39$ & -0.063 & $(0.173)$ & -0.086 & $(0.174)$ \\
\hline $40-54$ & $0.503 * *$ & $(0.167)$ & $0.459 * *$ & $(0.169)$ \\
\hline$\geq 55$ & $1.160 * *$ & $(0.237)$ & $1.040 * *$ & $(0.254)$ \\
\hline \multicolumn{5}{|l|}{ Education } \\
\hline $\begin{array}{r}\text { General secondary or } \\
\text { vocational }\end{array}$ & 0.034 & $(0.156)$ & 0.043 & $(0.158)$ \\
\hline $\begin{array}{r}\text { Professional secondary or } \\
\text { unfinished higher }\end{array}$ & 0.141 & $(0.167)$ & 0.135 & $(0.170)$ \\
\hline Higher & 0.017 & $(0.212)$ & 0.012 & $(0.213)$ \\
\hline \multicolumn{5}{|l|}{ Sources of Subsistence } \\
\hline Unemployment benefits & 0.111 & $(0.143)$ & 0.137 & $(0.144)$ \\
\hline Casual Work & 0.156 & $(0.124)$ & 0.166 & $(0.123)$ \\
\hline Household Income & $0.366^{*}$ & $(0.151)$ & $0.395 *$ & $(0.155)$ \\
\hline State Transfers & 0.198 & $(0.135)$ & - & \\
\hline Pension & - & & $0.342 *$ & $(0.173)$ \\
\hline Other state transfers & - & & 0.060 & $(0.171)$ \\
\hline Other SS & -0.181 & $(0.290)$ & -0.172 & $(0.292)$ \\
\hline Regional UR ${ }^{\# \#}$ & -0.018 & $(0.023)$ & -0.050 & $(0.037)$ \\
\hline \multicolumn{5}{|l|}{ Type of settlement } \\
\hline Town & $-0.339 *$ & $(0.134)$ & $-0.351 * *$ & $(0.133)$ \\
\hline Large city & -0.179 & $(0.158)$ & -0.256 & $(0.174)$ \\
\hline \multicolumn{5}{|l|}{ Previous unemployment } \\
\hline 1 prior spell & 0.092 & $(0.200)$ & 0.070 & $(0.201)$ \\
\hline 2 prior spells & 0.323 & $(0.518)$ & 0.284 & $(0.521)$ \\
\hline 3 or more prior spells & 0.964 & $(0.846)$ & 0.989 & $(0.845)$ \\
\hline Previously employed & $-0.592 * *$ & $(0.136)$ & $-0.587 * *$ & $(0.137)$ \\
\hline $\mathrm{N}$ & \multicolumn{2}{|c|}{$\begin{array}{c}35838 \text { spell-months } \\
-1870.263\end{array}$} & \multicolumn{2}{|c|}{$\begin{array}{c}35838 \text { spell-months } \\
-1868.983\end{array}$} \\
\hline
\end{tabular}

Note: Number of failures is 369. Figures reported are the estimated coefficients. Robust standard errors adjusted for clustering on individual identifier in parentheses. $* *$ and $*$ denote significance at the $1 \%$ and $5 \%$ levels, respectively. ${ }^{\#}$ Baseline hazard parameters are

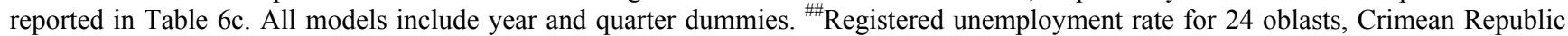
and Kiev City in specifications (1)-(3), (5)-(6) and ILO-type unemployment rate in specification (4). Exits to inactivity are considered censored when estimating exits to employment, and vice versa. 
Table 6c. Baseline hazard estimates from specification (3) in Tables 6a-6b

\begin{tabular}{|c|c|c|c|c|c|c|c|c|c|}
\hline \multirow[t]{2}{*}{ Month } & \multicolumn{2}{|c|}{$\begin{array}{l}\text { Exits to jobs, } \\
\text { multiple spells } \\
\text { (Table 6a) }\end{array}$} & \multicolumn{2}{|c|}{$\begin{array}{l}\text { Exits to inactivity, } \\
\text { multiple spells } \\
\text { (Table 6b) }\end{array}$} & \multirow[t]{2}{*}{ Month } & \multicolumn{2}{|c|}{$\begin{array}{l}\text { Exits to jobs, } \\
\text { multiple spells } \\
\text { (Table 6a) }\end{array}$} & \multicolumn{2}{|c|}{$\begin{array}{l}\text { Exits to inactivity, } \\
\text { multiple spells } \\
\text { (Table 6b) }\end{array}$} \\
\hline & Hazard & Std.Error & Hazard & Std.Error & & Hazard & Std.Error & Hazard & Std.Error \\
\hline 1 & 0.016 & $(0.005)$ & 0.000 & (0.000) & 53 & 0.103 & $(0.056)$ & 0.016 & $(0.011)$ \\
\hline 2 & 0.100 & $(0.023)$ & 0.001 & $(0.001)$ & 54 & 0.085 & $(0.052)$ & 0.024 & $\begin{array}{l}(0.015) \\
\end{array}$ \\
\hline 3 & 0.094 & $(0.022)$ & 0.002 & $(0.001)$ & 55 & 0.158 & $(0.077)$ & 0.014 & $(0.011)$ \\
\hline 4 & 0.080 & $(0.019)$ & 0.003 & $(0.001)$ & 56 & 0.111 & $(0.068)$ & - & \\
\hline 5 & 0.066 & $(0.016)$ & 0.002 & $(0.001)$ & 57 & 0.040 & $(0.040)$ & 0.009 & $\begin{array}{l}(0.009) \\
\end{array}$ \\
\hline 6 & 0.074 & $(0.018)$ & 0.002 & $(0.001)$ & 58 & 0.087 & $(0.063)$ & 0.019 & $(0.015)$ \\
\hline 7 & 0.070 & $(0.017)$ & 0.003 & $(0.001)$ & 59 & 0.250 & $(0.120)$ & - & \\
\hline 8 & 0.050 & $(0.013)$ & 0.001 & $(0.001)$ & 60 & 0.185 & $(0.114)$ & 0.029 & $(0.023)$ \\
\hline 9 & 0.052 & $(0.014)$ & 0.002 & $(0.001)$ & 61 & - & & 0.063 & $(0.042)$ \\
\hline 10 & 0.052 & $(0.014)$ & 0.002 & $(0.001)$ & 62 & 0.307 & $(0.186)$ & - & \\
\hline 11 & 0.051 & $(0.014)$ & 0.004 & $(0.002)$ & 63 & 0.271 & $(0.200)$ & - & \\
\hline 12 & 0.076 & $(0.020)$ & 0.003 & $(0.001)$ & 64 & 0.662 & $(0.356)$ & 0.085 & $(0.067)$ \\
\hline 13 & 0.068 & $(0.018)$ & 0.010 & $(0.004)$ & 65 & 0.800 & $(0.583)$ & 0.223 & $(0.188)$ \\
\hline 14 & 0.049 & $(0.014)$ & 0.002 & $(0.001)$ & & & & & \\
\hline 15 & 0.051 & $(0.015)$ & 0.002 & $(0.001)$ & & & & & \\
\hline 16 & 0.034 & $(0.012)$ & 0.002 & $(0.001)$ & & & & & \\
\hline 17 & 0.053 & $(0.016)$ & 0.003 & $(0.001)$ & & & & & \\
\hline 18 & 0.048 & $(0.015)$ & 0.001 & $(0.001)$ & & & & & \\
\hline 19 & 0.042 & $(0.014)$ & 0.001 & $(0.001)$ & & & & & \\
\hline 20 & 0.046 & $(0.015)$ & 0.001 & $(0.001)$ & & & & & \\
\hline 21 & 0.052 & $(0.016)$ & 0.002 & $(0.001)$ & & & & & \\
\hline 22 & 0.063 & $(0.019)$ & 0.002 & $(0.001)$ & & & & & \\
\hline 23 & 0.081 & $(0.023)$ & 0.002 & $(0.001)$ & & & & & \\
\hline 24 & 0.043 & $(0.015)$ & 0.004 & $(0.002)$ & & & & & \\
\hline 25 & 0.042 & $(0.015)$ & 0.006 & $(0.003)$ & & & & & \\
\hline 26 & 0.040 & $(0.015)$ & 0.004 & $(0.002)$ & & & & & \\
\hline 27 & 0.042 & $(0.016)$ & 0.003 & $(0.002)$ & & & & & \\
\hline 28 & 0.048 & $(0.017)$ & 0.002 & $(0.002)$ & & & & & \\
\hline 29 & 0.051 & $(0.019)$ & 0.003 & $(0.002)$ & & & & & \\
\hline 30 & 0.055 & $(0.020)$ & 0.002 & $(0.001)$ & & & & & \\
\hline 31 & 0.031 & $(0.014)$ & 0.005 & $(0.003)$ & & & & & \\
\hline 32 & 0.033 & $(0.015)$ & 0.005 & $(0.003)$ & & & & & \\
\hline 33 & 0.065 & $(0.023)$ & 0.005 & $(0.003)$ & & & & & \\
\hline 34 & 0.044 & $(0.019)$ & 0.003 & $(0.002)$ & & & & & \\
\hline 35 & 0.059 & $(0.023)$ & 0.011 & $(0.005)$ & & & & & \\
\hline 36 & 0.043 & $(0.019)$ & 0.011 & $(0.005)$ & & & & & \\
\hline 37 & 0.046 & $(0.021)$ & 0.009 & $(0.005)$ & & & & & \\
\hline 38 & 0.066 & $(0.027)$ & 0.006 & $(0.004)$ & & & & & \\
\hline 39 & 0.088 & $(0.033)$ & - & & & & & & \\
\hline 40 & 0.084 & $(0.032)$ & 0.004 & $\begin{array}{l}(0.003) \\
\end{array}$ & & & & & \\
\hline 41 & 0.069 & $(0.030)$ & 0.004 & $(0.003)$ & & & & & \\
\hline 42 & 0.073 & $(0.031)$ & 0.002 & $(0.002)$ & & & & & \\
\hline 43 & 0.090 & $(0.037)$ & 0.006 & $(0.004)$ & & & & & \\
\hline 44 & 0.037 & $(0.022)$ & 0.009 & $(0.005)$ & & & & & \\
\hline 45 & 0.026 & $(0.019)$ & 0.005 & $(0.004)$ & & & & & \\
\hline 46 & 0.056 & $(0.030)$ & 0.005 & $(0.004)$ & & & & & \\
\hline 47 & 0.075 & $(0.037)$ & - & & & & & & \\
\hline 48 & 0.064 & $(0.035)$ & 0.009 & $(0.006)$ & & & & & \\
\hline 49 & 0.069 & $(0.037)$ & 0.013 & $(0.008)$ & & & & & \\
\hline 50 & 0.095 & $(0.046)$ & 0.014 & $(0.009)$ & & & & & \\
\hline 51 & 0.089 & $(0.047)$ & 0.013 & $(0.009)$ & & & & & \\
\hline 52 & 0.049 & $(0.036)$ & 0.009 & $(0.007)$ & & & & & \\
\hline
\end{tabular}




\section{REFERENCES}

Addison, J.T. and P. Portugal (2001) Unemployment Duration: Competing and Defective Risks, IZA Discussion Paper No. 350.

Akerlof, G. A. and J. L. Yellen (1985) Unemployment through the Filter of Memory, Quarterly Journal of Economics 100(3), 747-773.

Arulampalam, W. and M.S. Stewart (1995) The Determinants of Individual Unemployment Durations in an Era of High Unemployment, The Economic Journal 105, 321-332.

Bean, C. (1994) European Unemployment: A Survey, Journal of Economic Literature 32(2), 573-619.

Blanchard, O. (1997) The Economics of Post-Communist Transition (Oxford: Clarendon Press).

Boeri, T. (2001) Transition with Labor Supply, IZA Discussion Paper No. 257.

Boeri, T. and K. Terrell (2002) Institutional Determinants of Labor Reallocation in Transition, Journal of Economic Perspectives 16(1), 51-76.

Commander, S. and F. Coricelli (1994) Unemployment, Restructuring, and the Labor Market in Eastern Europe and Russia (Washington, D.C: The World Bank).

Commander, S. and R. Yemtsov (1994) Russian Unemployment: Its Magnitude, Characteristics, and Regional Dimensions, World Bank Policy Research Working Paper No. 1426.

Cox D. R. (1972) Regression Models and Life-Tables, Journal of the Royal Statistical Society B34, 187-220.

Denisova, I. (2002) Staying Longer in Unemployment Registry in Russia: Lack of Education, Bad Luck or Something Else?, Materials presented at the conference on State of Economics and of Transition Honoring 10years of the NES (December 2002, Moscow).

Dex, S. and A. McCulloch (1998) The Reliability of Retrospective Unemployment History Data, Work, Employment and Society 12(3), 497-509.

Earle, J. and C. Pauna (1996) Incidence and Duration of Unemployment in Romania, European Economic Review 40, 829-837.

Earle, J. and K. Sabirianova (2000) Equilibrium Wage Arrears: A theoretical and Empirical Analysis of Institutional Lock-in, IZA Discussion Paper No. 196.

Foley, M. C. (1997a) Determinants of Unemployment Duration in Russia, Yale University, Economic Growth Center Discussion Paper No. 779.

Foley, M. C. (1997b) Labor Market Dynamics in Russia, Yale University, Economic Growth Center Discussion Paper No. 780.

Grogan, L. and G.J. van den Berg (1999). The Duration of Unemployment in Russia, Tinbergen Institute Discussion Paper No. 99-011.

Ham, J., J. Svejnar and K. Terrell (1998) Unemployment and Social Safety Net During Transitions to a Market Economy: Evidence from the Czech and Slovak Republics, American Economic Review 88, 1117-1142.

Han, A. and J. Hausman (1990) Flexible Parametric Estimation of Duration and Competing Risks Models, Journal of Applied Econometrics 5, 1-28.

Hunt, J. (1995) The Effect of Unemployment Compensation on Unemployment Duration in Germany, Journal of Labor Economics 13(1), 88-120.

ILO (1982) Guidelines on Measuring Employment and Unemployment at http://www.hamburg.embjapan.go.jp/infojp/wussten/dilo.html 
Kapelyushnikov, R. and N. Vishnevskaya (2003) Russian Unemployment: Dynamics, Composition, and Specificity (Moscow: Moscow Public Science Foundation).

Kiefer, N. M. (1988) Economic Duration Data and Hazard Functions, Journal of Economic Literature 26(2), 646-679.

Kupets, O. (2000) The Impact of Active Labor Market Policies on the Outflows from Unemployment to Regular Jobs in Ukraine, Master of Arts Thesis (EERC, Kiev).

Kuzmin, M., Y. Kuzmin, and O. Kupets (2003) Analiz Derzhavnoj Polityky Zajnyatosti v Ukrajni (Analysis of State Employment Policy in Ukraine) (Kiev: Milennium).

Lancaster, T. (1990) The Econometric Analysis of Transition Data (Cambridge: Cambridge University Press).

Lehmann, H., J. Wadsworth and A. Acquisti (1999) Grime and Punishment: Insecurity and Wage Arrears in the Russian Federation, Journal of Comparative Economics 27, 595-617.

Meyer, B. D. (1990) Unemployment Insurance and Unemployment Spells, Econometrica 58(4), 757 782.

Mel'ota, I. and P. Gregory (2001) New Insights into Ukraine's Shadow Economy: Has it Already Been Counted?, Institute for Economic Research and Policy Consulting Working Paper No.11.

Mortensen, D. (1970) Job search, the Duration of Unemployment and the Phillips Curve, American Economic Review 30, 847-862.

Morgenstern, R. D. and N. S. Barrett (1974) The Retrospective Bias in Unemployment Reporting by Sex, Race and Age, Journal of the American Statistical Association 69, 355-357.

Narendranathan, W. and M.B. Stewart (1993) Modeling the Probability Models of Leaving Unemployment: Competing Risks Models with Flexible Baseline Hazards, Journal of the Royal Statistical Society C42(1), 63-83.

Nivorozhkina, L., E. Nivorozhkin and A. Shukhmin (2002) Modeling Labor Market Behavior of the Population of a Large Industrial City: Duration of Registered Unemployment, EERC Working Paper No. 01-08.

Paull, G. (2002) Biases in the Reporting of Labor Market Dynamics, Institute for Fiscal Studies Working Paper No.02/10.

Poterba, J. M. and L. H. Summers (1995) Unemployment Benefits and Labor Market Transitions: A Multinomial Logit Model with Errors in Classification, Review of Economics and Statistics 77(2), $207-$ 216.

Sabirianova K. P. (1998) Microeconomicheskij Analiz Dinamicheskih Izmenenij na Rossijskom Rynke Truda (Microeconomic Analysis of Dynamic Changes at the Russian Labor Market), Voprosy Economiki 1, 42-58.

Stetsenko, S. (2003) On the Duration and the Determinants of Ukrainian Registered Unemployment. A Case Study of Kyiv, Master of Arts Thesis (EERC, Kiev).

Sudman, S. and N. M. Bradburn (1973) Effects of Time and Memory Factors on Response in Surveys, Journal of the American Statistical Association 68, 805-815.

Vodopivec, M. (1995) Unemployment Insurance and Duration of Unemployment: Evidence form Slovenia's Transition, World Bank Policy Research Working Paper No. 1552. 


\section{APPENDICES}

\section{APPENDIX 1. UNEMPLOYMENT INSURANCE SYSTEM IN UKRAINE: REGULATORY FRAMEWORK}

The main principles of unemployment benefit (insurance from 2001) system in Ukraine are set forth in the Law on Employment (came into effect in 1991), the Law on Compulsory State Social Unemployment Insurance (came into effect in 2001) and some auxiliary elements of the law which regulate relations connected with unemployment insurance. According to the Law on Compulsory State Social Unemployment Insurance only those individuals who are officially registered as unemployed with a local employment center can be eligible for unemployment benefits.

Under the Law of Ukraine on Employment the unemployed are working-age, able-bodied persons who are without work and earnings, are registered with state employment center as looking for a job, able and ready to start a suitable job (Article 2). The unemployment status is granted on the eighth day after applying to the local employment center. The unemployed status is denied to persons under sixteen (with exception of those who worked before and were laid off), to persons looking for their first job if they had no profession or skill and if they refused an offer of vocational training or of gainful employment, to persons eligible for pension according to the legislation, and to persons who within 7 days after registration with a local employment center as looking for a job rejected two offers of suitable job.

The unemployment benefit is paid from the eighth day after the date of registration in the PES till reemployment but duration of unemployment benefit payment is limited to 360 days during two years for the majority of the unemployed, to 720 days for people of pre-retirement age (men of 58 or older and women of 53 or older), and to 180 days for uninsured individuals with unemployment status looking for their first work and for some categories of dismissed military employees. If a person is registered as unemployed for a second time during two years, duration of unemployment benefit payment during the second unemployment spell is calculated as the residual from the maximum specified duration during two years and actual duration of unemployment benefit payment during the first unemployment spell.

To remain in the register and to receive unemployment benefits without suspension or reductions up to 90 days an unemployed must report to the local employment center once a month, follow recommendations of the employment center aimed at encouraging employment, not refuse two offers of a suitable job or an offer of training/retraining, not refuse a job offer with new qualifications after retraining, not leave training/retraining courses without valid reason, and not conceal information about temporary employment while receiving unemployment benefits. If a person voluntarily quitted a job without strong reasons or he/she was dismissed for disciplinary reasons, payment of unemployment benefits begins from the $91^{\text {st }}$ day after registration. Benefits are also postponed up to 3 months to individuals receiving severance payment and other payments after lay-offs. Unemployment benefits can be paid as a lump sum to unemployed individuals older than 18 who intend to start their own business after approving their business-plans by the special committee of the employment center and their registration as a subject of entrepreneurial activity (physical or juridical entity) in the State Tax Administration.

According to the Law on Compulsory State Social Unemployment Insurance size of unemployment benefit 
depends on the reason of unemployment, length of unemployment insurance payment (equal to sum of work experience before 2001 and length of actual unemployment insurance payment from 2001), average wage at the previous work and duration of unemployment. ${ }^{24}$

1) If an insured person worked (including various forms of employment) and paid unemployment insurance contributions for at least 26 weeks during the last 12 months before the unemployment period, was laid off by independent of him reasons, is registered on general conditions and is entitled to unemployment benefits, the size of his unemployment benefit is calculated as a percentage of his average wage at the previous work depending on the length of unemployment insurance payment according to the following scheme:

\begin{tabular}{|l|c|}
\hline $\begin{array}{c}\text { Length of unemployment } \\
\text { insurance payment }\end{array}$ & $\begin{array}{c}\text { Intermediate size of unemployment benefits } \\
\text { as a percentage of average wage (IUB) }\end{array}$ \\
\hline less than 2 years & $50 \%$ \\
\hline from 2 to 6 years & $55 \%$ \\
\hline from 6 to 10 years & $60 \%$ \\
\hline more than 10 years & $70 \%$ \\
\hline
\end{tabular}

Then, depending on duration of unemployment spell the final size of benefits is defined as a percentage of the specified amount IUB: $100 \%$ during first 90 days, $80 \%$ during the following 90 days, and $70 \%$ afterwards. As a result, pattern of defining the size of unemployment benefits as a percentage of the average wage at the previous work can be expressed as shown in the table below:

\begin{tabular}{|c|l|c|}
\hline $\begin{array}{c}\text { Length of } \\
\text { unemployment insurance } \\
\text { payment }\end{array}$ & \multicolumn{1}{|c|}{$\begin{array}{c}\text { Duration of } \\
\text { unemployment }\end{array}$} & $\begin{array}{c}\text { Size of unemployment } \\
\text { benefits as a percentage } \\
\text { of average wage }\end{array}$ \\
\hline \multirow{3}{*}{ less than 2 years } & first 90 days & $50 \%$ \\
following 90 days & $40 \%$ \\
the rest & $35 \%$ \\
\hline \multirow{2}{*}{ from 2 to 6 years } & first 90 days & $55 \%$ \\
& following 90 days & $44 \%$ \\
from 6 to 10 years & first 90 days & $38.5 \%$ \\
\hline \multirow{3}{*}{ more than 10 years } & following 90 days & $60 \%$ \\
& the rest & $48 \%$ \\
& first 90 days & $42 \%$ \\
\hline
\end{tabular}

However, unemployment benefits cannot exceed the regional average wage in the previous month and cannot be lower than the subsistence minimum.

2) If an insured person worked (including various forms of employment) and paid unemployment insurance contributions for at least 26 weeks during the last 12 months before the unemployment period, has quitted a job without strong reasons, is registered on general conditions and is entitled to unemployment benefits, the size of

\footnotetext{
${ }^{24}$ Before the Law on Compulsory State Social Unemployment Insurance came into effect in 2001, size of unemployment benefit depended on the reason of unemployment (the same categories as now), average wage at the previous work and duration of unemployment (only for laid-off persons for economic reasons), but not on the length of actual unemployment insurance payment (or, in other words, work experience). So if persons were laid-off by economic reasons and worked for at least 26 weeks during the last 12 months before the unemployment period, replacement rate was $100 \%$ during first 60 days, $75 \%$ during the following 90 days and 50\% during 210 days; if persons worked less than 26 weeks they were eligible to unemployment benefits of no less than $50 \%$ of their previous wage; and all other persons were eligible for the established minimum level of unemployment benefits.
} 
his unemployment benefit is calculated by the same scheme as in p.1) but payment of unemployment benefits starts from the $91^{\text {st }}$ day at the amount of $80 \%$ of the specified amount IUB.

3) The size of benefits paid to all other categories (insured as well as uninsured, including those who were dismissed for disciplinary reasons; those who worked or paid unemployment insurance contributions for less than 26 weeks in the last 12 months before becoming unemployed; those who are willing to reenter employment after a long (more than six months) break; those who worked or were engaging in entrepreneurial activity at least 26 weeks in the last 12 months before becoming unemployed, didn't pay unemployment insurance contributions but have work experience (equated to insurance experience) or insurance experience acquired before; those who are seeking for a job for the first time and have no insurance experience; some categories of dismissed military employees, etc.) doesn't depend on the length of unemployment insurance payment and is set at the level of the subsistence minimum established by the law.

4) Persons who worked or were engaging in entrepreneurial activity at least 26 weeks in the last 12 months before becoming unemployed, didn't pay unemployment insurance contributions and don't have work experience (equated to insurance experience) or insurance experience acquired before are not eligible for unemployment benefits.

If unemployed persons attend training or retraining courses, they are eligible for a stipend at the level of unemployment benefit calculated according to the above rules but the size of their stipend can not be changed during training course depending on the duration of unemployment spell and is equal to the size defined at the beginning of training program. Duration of stipend payment is scored up to the general duration of unemployment benefits payment and cannot exceed it.

If unemployed workers have less than one and a half years until legal retirement age, they may be provided with a regular pension instead of unemployment benefits at the expense of the Unemployment Insurance Fund.

Persons registered as unemployed who have already exhausted their unemployment insurance benefits are entitled to unemployment assistance if the average per capita income in their families does not exceed the level of the subsistence minimum established by the law. Unemployment assistance to the unemployed is paid at the monthly level of $75 \%$ of the subsistence minimum during 180 days.

Persons who have already exhausted their unemployment benefits and unemployment assistance or their non working-able dependants can be eligible to one-off cash payment at the level of $50 \%$ of the subsistence minimum. In the case of death of an unemployed person or his/her dependant, the funeral assistance in the amount of one subsistence minimum is given to his/her relatives. 


\section{APPENDIX 2. DEFINITION OF VARIABLES}

\begin{tabular}{|c|c|}
\hline Variable & Definition \\
\hline Duration of unemployment & $\begin{array}{l}\text { The number of full months between the date of beginning of job search (month } \\
\text { and year only) to the date of its end }\end{array}$ \\
\hline Female & $=1$ if Female \\
\hline Married & $\begin{array}{l}=1 \text { if legally married or cohabiting (i.e. in non-registered marriage), }=0 \text { otherwise } \\
\text { (never married, divorced, widowed or separated) }\end{array}$ \\
\hline Number of children & $=$ Integer number from 0 to 4, number of small children aged 15 or less \\
\hline Age & $\begin{array}{l}\text { Three dummy variables for the corresponding age group: from } 25 \text { to } 39 \text {, from } 40 \\
\text { to } 54 \text {, and } 55 \text { or older; reference age group is full } 24 \text { years and under }\end{array}$ \\
\hline Education & $\begin{array}{l}\text { Three dummy variables for the corresponding level of education: general } \\
\text { secondary or vocational (diploma of high-school or PTU); professional secondary } \\
\text { or unfinished higher (diploma of college or at least } 3 \text { years of study at the } \\
\text { institute/university); higher (diploma of institute/university, any degree); reference } \\
\text { education group is primary or unfinished secondary) }\end{array}$ \\
\hline Unemployment Benefits & $\begin{array}{l}=1 \text { if received unemployment benefits or training allowance during an } \\
\text { unemployment spell }\end{array}$ \\
\hline Casual Work & $\begin{array}{l}=1 \text { if received income from casual work, production and sale of products from } \\
\text { own land plot, from casual business activities or engaged in subsidiary farming for } \\
\text { own needs }\end{array}$ \\
\hline Household Income & $\begin{array}{l}=1 \text { if lived on income of spouse or parents or support from relatives during a } \\
\text { period of unemployment }\end{array}$ \\
\hline State Transfers & $\begin{array}{l}=1 \text { if lived on pension, stipend or study loan, child allowance, alimony, social } \\
\text { benefits, subsistence allowance, or support by state or municipal institution during } \\
\text { a period of unemployment (also, Pension }=1 \text { if pension) }\end{array}$ \\
\hline $\begin{array}{l}\text { Other sources of } \\
\text { subsistence }\end{array}$ & $=1$ if lived on income from sale of property or rent, dividends, loans or savings \\
\hline Regional UR & $\begin{array}{l}\text { Quarterly registered oblast-level unemployment rate ( } 24 \text { oblasts, Kyiv City and } \\
\text { Crimean Republic) where a person lived at the beginning of an unemployment } \\
\text { spell in specifications (1)-(3), (5)-(6) and average yearly ILO-defined oblast-level } \\
\text { unemployment rate in specification (4). }\end{array}$ \\
\hline Type of settlement & $\begin{array}{l}\text { Two dummy variables for the corresponding type of settlement where where an } \\
\text { individual lived at the beginning of an unemployment spell: town (from } 20 \text { to } 500 \\
\text { thds. inhabitants), large city (more than } 500 \text { thds. inhabitants) }\end{array}$ \\
\hline Previous labor market state & $\begin{array}{l}=1 \text { if employed prior to the start of unemployment, }=0 \text { if previously inactive for } \\
\text { more than } 1 \text { month }\end{array}$ \\
\hline $\begin{array}{l}\text { Net wage in the last job } \\
\text { before becoming } \\
\text { unemployed } \\
\text { Log (Real Last Wage) }\end{array}$ & $\begin{array}{l}\text { The logarithm of last net contractual monthly wage deflated by the national } \\
\text { monthly CPI (January } 1997=100 \text { ) }\end{array}$ \\
\hline
\end{tabular}


APPENDIX 3. EMPIRICAL SURVIVAL AND HAZARD FUNCTIONS

Figure 1. Empirical Survival Function - All Exits from Unemployment

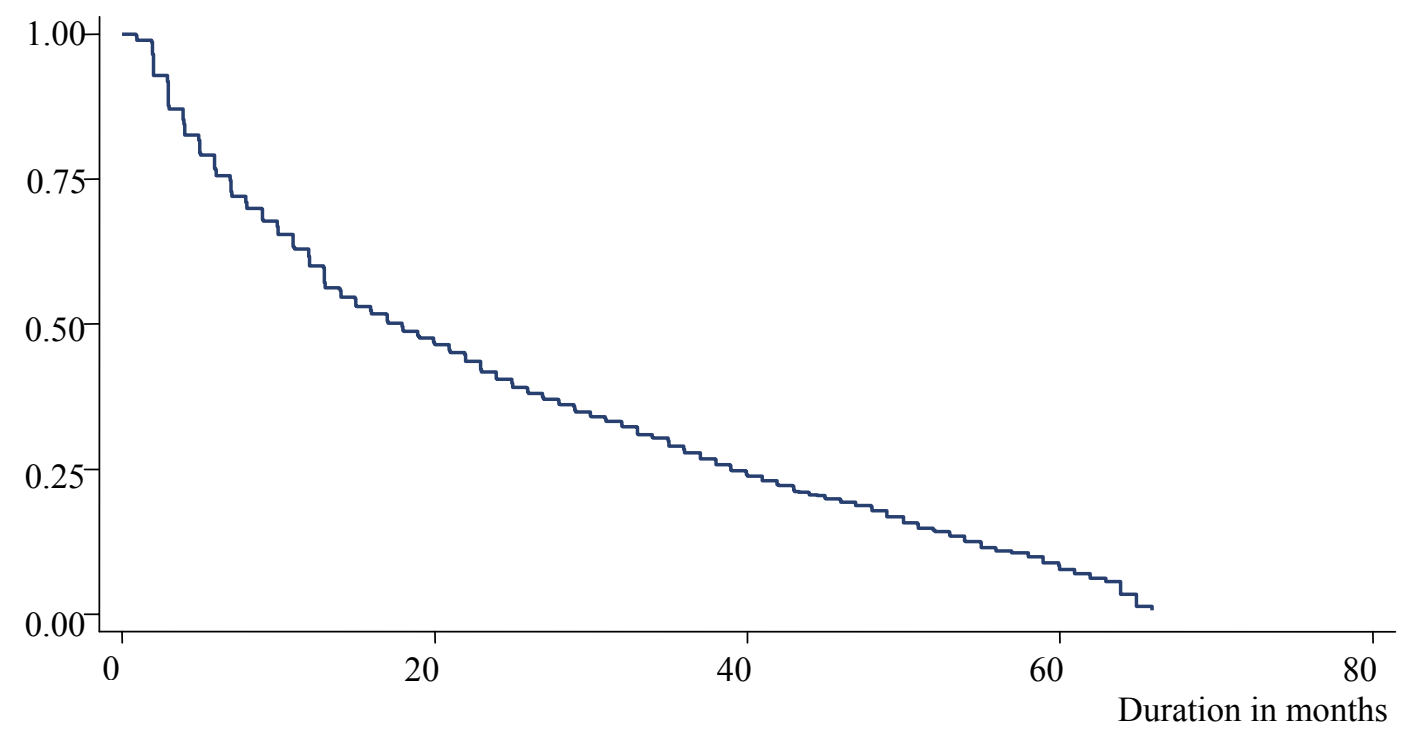

Figure 2. Empirical Hazard Function - All Exits from Unemployment

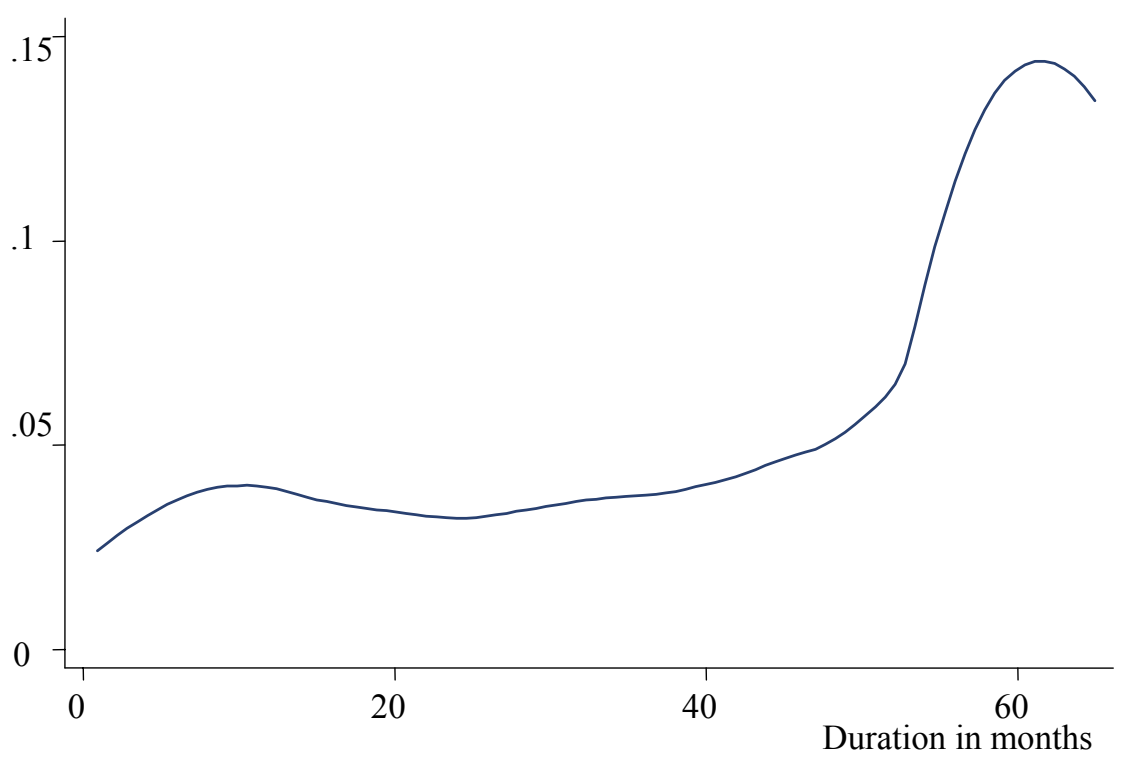


Figure 3. Empirical Survival Functions - Exits from Unemployment by Destination State
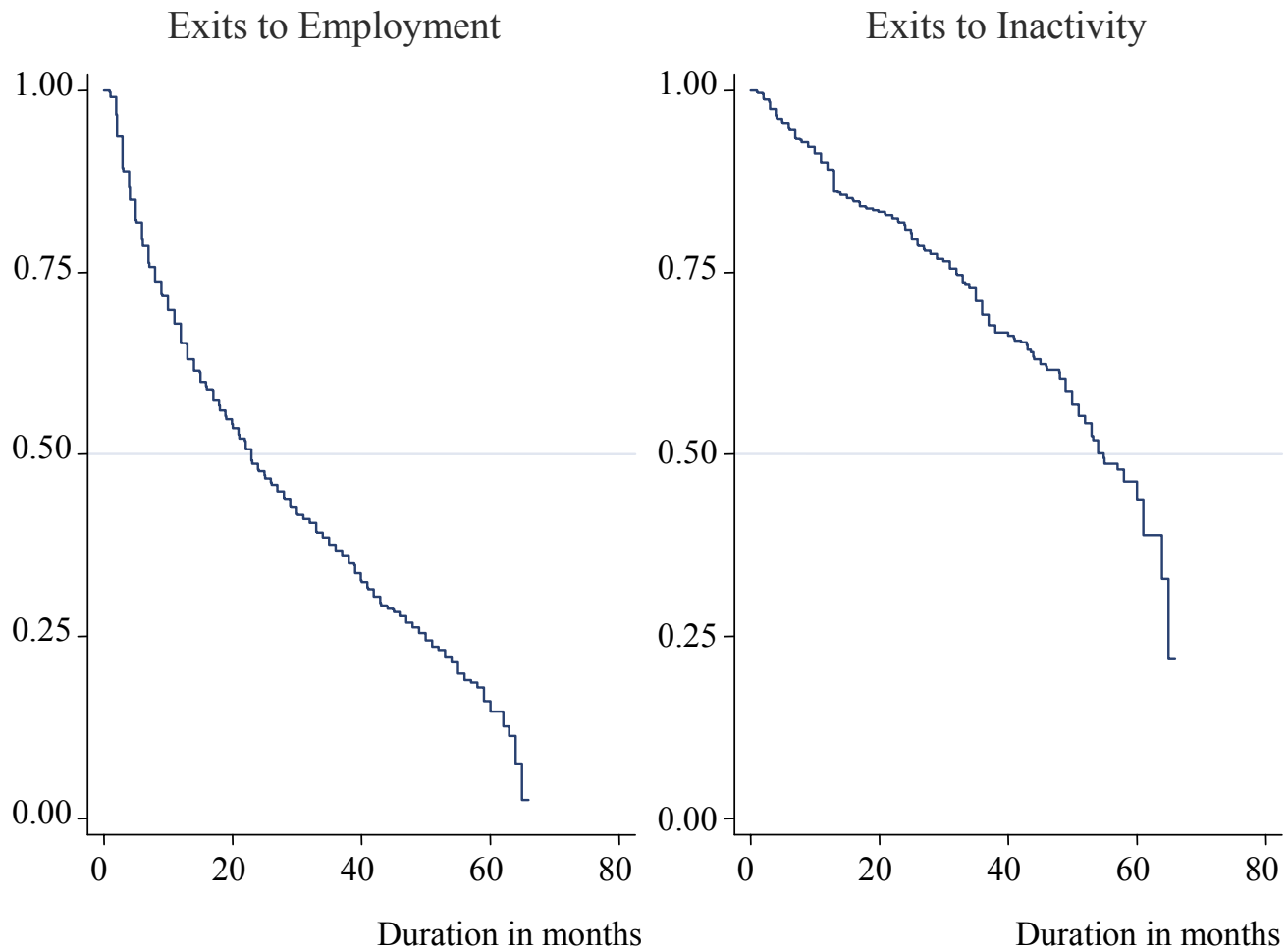

Figure 4. Empirical Hazard Functions - Exits from Unemployment by Destination State Exits to Employment

Exits to Inactivity
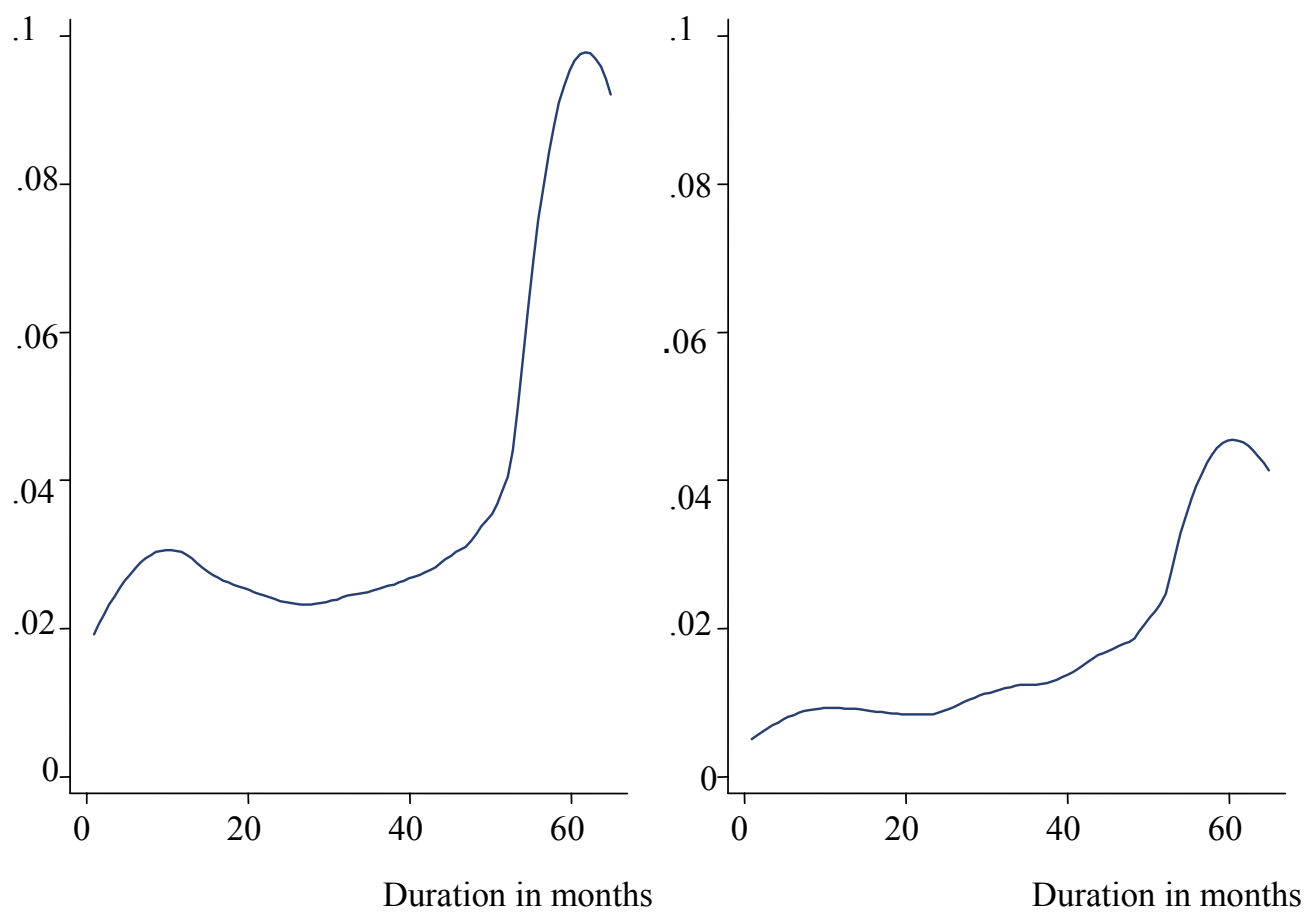